\title{
DOCTRINA DEL TRIBUNAL CONSTITUCIONAL \\ DURANTE EL PRIMER CUATRIMESTRE DE 2018
}

Doctrine of the Constitutional Court during

the First Four-Month Period of 2018

\author{
JUAN CARLOS DUQUE VILLANUEVA \\ duque@tribunalconstitucional.es
}

CARLOS ORTEGA CARBALLO

carlos.ortega@defensordelpueblo.es

HERMINIO LOSADA GONZÁLEZ

losada@tribunalconstitucional.es

TOMÁS DE LA QUADRA-SALCEDO JANINI

tquadra@tribunalconstitucional.es 
I. JURISDICCIÓN CONSTITUCIONAL. DERECHO PROCESAL CONSTITUCIONAL. II. FUENTES DEL DERECHO. III. ESTRUCTURA TERRITORIAL DEL ESTADO. IV. ORGANIZACIÓN DE LOS PODERES PÚBLICOS. V. DERECHOS FUNDAMENTALES.

\section{JURISDICCIÓN CONSTITUCIONAL. DERECHO PROCESAL CONSTITUCIONAL}

1. La decisión más relevante del TC en materia procesal durante el primer cuatrimestre de este ańo es, sin duda, por su novedad, el ATC 5/2018 (Pleno), de 27 de enero, dictado en la impugnación promovida por el Gobierno de la Nación (arts. 162.1 CE y 76 y 77 LOTC) contra las resoluciones del presidente del Parlamento de Cataluña por las que, respectivamente, se propone a don Carles Puigdemont y Casamajó como candidato a presidente de la Generalitat y se convoca sesión para el debate y votación de su investidura, instándose la suspensión de aquellas resoluciones.

El TC admite, con base en el precedente ATC 135/2004 (Pleno), de 20 de abril, la personación en el proceso de los diputados del Parlamento de Cataluña que la han solicitado, pues la resolución de la impugnación puede incidir en sus derechos e intereses legítimos (FJ 2). Acuerda también, a la vista del motivo de oposición a la admisión aducido por los citados diputados —el carácter preventivo de la impugnación, ya que, frente a lo sostenido en la demanda, no puede descartarse la presencia del candidato en la Cámara—, la apertura de un trámite de audiencia para que las partes aleguen sobre los presupuestos procesales de admisibilidad (FJ 3).

Por lo que respecta a la solicitud de suspensión de las resoluciones objeto del proceso, el TC parte de la consideración de que la medida de suspensión del art. 162.1 CE «tiene una naturaleza mixta», dado que, por un lado, constituye una potestad constitucionalmente conferida al Gobierno, cuya expresa petición el TC debe atender cuando se acuerde la admisión a trámite de la impugnación; y, por otro, se trata de una medida cautelar, según se deduce del último inciso del art. 162.1 CE, al establecer que el TC debe ratificar o levantar en un plazo no superior a cinco meses la suspensión inicialmente acordada, "pues obliga a tener en cuenta para su ratificación o levantamiento la finalidad de evitar que la eficacia del acto impugnado pueda ocasionar daños de difícil o imposible reparación que puedan hacer perder al recurso o 
impugnación su finalidad». Tras poner de manifiesto la inexistencia de precedentes, el TC entiende que en los casos en que se posponga la decisión de admisión puede acordar como medida cautelar, "por razones de urgencia excepcional», la suspensión de los efectos que se puedan derivar de los actos impugnados que puedan ocasionar daños de imposible o difícil reparación, "garantizando de este modo que si finalmente se decide la admisión de la impugnación quede preservada la prerrogativa del Gobierno» (FJ 4).

En consecuencia, a fin de preservar la finalidad de la prerrogativa que el art. 162.1 CE confiere al Gobierno, el TC acuerda como medida cautelar, en tanto se pronuncia sobre la admisibilidad de la impugnación, suspender cualquier sesión de investidura que no sea presencial y que no cumpla las siguientes condiciones: a) no podrá celebrarse el debate y votación de la investidura de don Carles Puigdemont i Casamajó como candidato a presidente de la Generalitat a través de medios telemáticos ni por sustitución de otro parlamentario; b) no podrá procederse a la investidura del candidato sin la pertinente autorización judicial, aunque comparezca personalmente en la Cámara, si está vigente una orden judicial de busca y captura e ingreso en prisión; y c) los miembros de la Cámara sobre los que pesa un orden judicial de busca y captura e ingreso en prisión no podrán delegar el voto en otros parlamentarios (FJ 5).

A juicio del TC existen razones tanto procesales como sustantivas que justifican en este caso la adopción de la medida cautelar descrita. En cuanto a las primeras, porque la apertura del trámite de audiencia para que las partes aleguen sobre la admisibilidad de la impugnación no "puede conllevar que se malogre plenamente, de admitirse al final esta impugnación, aquella prerrogativa del Gobierno para la inmediata suspensión de las resoluciones recurridas». Y por lo que a las segundas se refiere, porque concurre una situación de urgencia excepcional, al haberse convocado ya la sesión de investidura y dada la situación procesal en la que se encuentra el candidato propuesto, en la que precisamente el Gobierno fundamenta la suspensión de las resoluciones objeto del proceso $(\mathrm{FJ} 5)^{1}$.

Por ATC 49/2018 (Pleno), de 26 de abril, se admite a trámite la impugnación promovida por el Gobierno contra las referidas resoluciones del presidente del Parlamento de Cataluña y se acuerda su suspensión desde la fecha de interposición de la demanda. El TC estima aquellas resoluciones objeto

Por ATC 6/2018 (Pleno), de 30 de enero, se desestimó, con base, en síntesis, en los mismos razonamientos, la solicitud de declaración de total nulidad e ineficacia del ATC 5/2018, promovida por la representación procesal de los diputados del Parlamento de Cataluña que se han tenido por personados en la impugnación. 
idóneo del proceso constitucional por tratarse de actos que tienen naturaleza jurídica, al haber sido dictados por el presidente del Parlamento en el ejercicio de sus funciones institucionales; al poseer también efectos jurídicos, ya que son actos necesarios para poder investir al presidente de la Generalitat; y, en fin, por emanar de un órgano capaz de expresar la voluntad institucional de la comunidad autónoma. En este último extremo, su condición de actos de trámite, al formar parte del procedimiento para la designación de presidente de la Generalitat, sin que lo finalicen, no constituye obstáculo para su consideración de actos expresivos de la voluntad institucional de la comunidad autónoma, puesto que «expresan la voluntad cierta y acabada del Presidente de la Cámara en el ejercicio de la función institucional que tiene atribuida de proponer a un candidato para el referido cargo y proceder a su investidura» (FJ 3).

El TC también rechaza el supuesto carácter preventivo e hipotético de la impugnación, ya que la conformidad a derecho de las resoluciones objeto de la misma y la viabilidad de la candidatura propuesta requieren resolver si la comparecencia personal del candidato en la Cámara es exigible y ha de obtener una previa autorización judicial en tanto esté vigente la orden de búsqueda y captura e ingreso en prisión. Además — se afirma en el auto — las dudas sobre el carácter hipotético de la impugnación han quedado despejadas por la decisión del presidente del Parlamento de aplazar la sesión de investidura hasta que el TC se pronuncie sobre la admisibilidad de la impugnación (FJ 2).

2. En relación con el recurso de inconstitucionalidad, el TC en la STC 2/2018 (Pleno), de 11 de enero, desestima la extemporaneidad aducida por la Asamblea de Extremadura por haberse interpuesto el recurso frente a una ley cuya aprobación es resultado de la tramitación parlamentaria de un decreto ley convalidado, coincidiendo además casi literalmente los preceptos de ambas normas, pues la consecuencia de la aprobación sucesiva de dos normas del mismo rango y del mismo contenido es la sustitución de la primera por la segunda en virtud del criterio lex posterior derogat priori, sin que en nuestro ordenamiento jurídico sea precisa la derogación explícita de un decreto ley que tras su tramitación parlamentaria como proyecto de ley se sustituye por una nueva ley [FJ 2 a)].

También rechaza el TC la denunciada falta de legitimación de la presidenta del Gobierno, en su condición de presidente del Gobierno en funciones, para interponer el recurso de inconstitucionalidad por encontrarse este en el territorio nacional y no haber vencido aún el plazo para la interposición del recurso. Se afirma en la sentencia que en supuestos de suplencia por ausencia del presidente del Gobierno es el mismo órgano el que actúa, esto es, el que interpone el recurso de inconstitucionalidad, con independencia de la persona 
física que desempeñe en ese momento el cargo. Así pues, la presidenta del Gobierno en funciones por ausencia temporal del presidente «está plenamente legitimada para interponer el recurso de inconstitucionalidad», sin que exista base jurídica alguna para diferenciar entre la ausencia temporal del presidente del Gobierno "dentro o fuera" del territorio nacional, ni para exigir "que la situación de ausencia tenga una determinada duración o deba extenderse hasta la finalización del plazo en que el titular del órgano debe ejercer la correspondiente función, facultad o potestad» para que puedan ser ejercidas en régimen de suplencia [FJ $2 \mathrm{~b}$ )].

Por su parte, las SSTC 14/2018 (Pleno), de 20 de febrero ${ }^{2}$, y 31/2018 (Pleno), de 10 de abril, inadmiten las solicitudes de adhesión del Parlamento de Navarra a sendos recursos de inconstitucionalidad, al no prever la LOTC en este proceso constitucional «la intervención pasiva de terceros que no hayan sido recurrentes y que no hayan esgrimido la acción dentro del plazo específicamente establecido para ello». Con invocación de la doctrina del ATC 18/1985, de 15 de enero (FJ 3), el TC sostiene que no procede acceder a la pretensión de adhesión al recurso de quien «en el momento inicial no manifestó voluntad alguna» y, por tanto, "no ejerció la acción de la que estaba asististido", tratando ahora de adherirse a un proceso abierto por otros, sin haber ejercido en plazo, pudiendo haberlo hecho, la acción para la que estaba legitimado (FFJJ 2).

Y la STC 16/2018 (Pleno), de 22 de febrero, reitera que el TC al decidir sobre la admisión de un recurso de inconstitucionalidad debe regirse únicamente por la LOTC, que no supedita dicha decisión a que la Comisión Permanente del Consejo de Estado haya emitido o emita en un momento posterior a la interposición del recurso el informe previo sobre la norma autonómica impugnada (art. 22.6 Ley Orgánica 3/1980, de 22 de abril, del Consejo de Estado), ni mucho menos a que dicho informe sea favorable a la impugnación, de modo que tampoco existe obstáculo alguno para que se recurran preceptos respecto de los que «el alto cuerpo consultivo no ha sido consultado» o estime que no «halla en ellos razón para impugnarlos» (FJ 3).

3. Por lo que se refiere a los conflictos entre órganos constitucionales, la STC 34/2018, de 12 de abril (Pleno) ${ }^{3}$, cuyo pronunciamiento al respecto reitera la STC 44/2018 (Pleno), de 26 de abril [FJ 2 a)], confirma la doctrina que en relación con la delimitación del objeto de este tipo de proceso se había hecho en la STC 234/2000, de 3 de octubre, ampliando la más restrictiva

2 Véase también infra pp. 246-249.

3 Véase también infra pp. 261-264. 
concepción plasmada en la inicial STC 45/1986, de 17 de abril. En efecto, en tanto que en la última de las sentencias citadas el TC había circunscrito el objeto de los conflictos entre órganos constitucionales exclusivamente a los supuestos de estricta vindicatio potestatis, esto es, de usurpación de atribuciones como consecuencia del ejercicio de una competencia ajena por parte de un órgano constitucional, en la STC 234/2000 amplió el objeto del proceso constitucional a los casos en los que el ejercicio de una competencia propia por un órgano constitucional puede implicar el menoscabo de una competencia también propia de otro órgano constitucional. Con base en dicha ampliación, el TC considera en la STC 34/2018 que los acuerdos impugnados de la Mesa del Congreso de los Diputados que rechazaron la disconformidad gubernamental a la tramitación de una iniciativa legislativa en ejercicio de la facultad de veto presupuestario que le confiere el art. 134.6 CE se adecuan al objeto propio del conflicto entre órganos constitucionales, en la medida en que el Gobierno considera que aquellos acuerdos menoscaban o lesionan su facultad constitucional de veto presupuestario [FJ 3 a)].

4. El criterio excepcional del fumus boni iuris ha estado presente durante este cuatrimestre en la resolución de no pocos incidentes sobre el levantamiento o mantenimiento de la suspensión de las disposiciones autonómicas impugnadas. Aquel criterio, recuerda el TC en el ATC 11/2018 (Pleno), de 7 de febrero, resulta aplicable cuando los preceptos impugnados sobre los que versa el incidente contienen previsiones muy similares («similitud intensa o coincidencia literal») con otros preceptos ya declarados inconstitucionales y nulos, siendo necesario para que opere dicho criterio que se identifiquen las concretas sentencias que hayan declarado la inconstitucionalidad y nulidad de preceptos idénticos o muy similares a los que son objeto del incidente de suspensión (FJ 3).

En aplicación de dicho criterio, el TC mantiene en el referido auto la suspensión de algunos de los preceptos impugnados de la Ley de Cataluña 17/2017, de 1 de agosto, del Código Tributario, dada «su intensa similitud [...] con las disposiciones autonómicas declaradas inconstitucionales y nulas en la STC 238/2015» (FFJJ 5 y 6). También se recurre a este criterio en el ATC 33/2018 (Pleno), de 21 de marzo, en el incidente sobre el levantamiento o mantenimiento de la suspensión de la Ley de Cataluña 13/2017, de 6 de julio, de las Asociaciones de Consumidores de Cannabis, por coincidir sustancialmente con la Ley Foral 24/2014, de 2 de diciembre, reguladora de los colectivos de usuarios de cannabis en Navarra, declarada inconstitucional y

4 Reseñada en REDC, núm. 61, 2001, pp. 260-261 y 263-265. 
nula por razones competenciales en la STC 114/2017, de 14 de diciembre. Asimismo, el TC invoca el criterio del fumus boni iuris para mantener la suspensión de algunos de los preceptos recurridos de la Ley de Cataluña 18/2017, de 1 de agosto, de Comercio, por la similitud que presentan con determinados preceptos declarados inconstitucionales y nulos en las SSTC 211/2016, de 15 de diciembre, y 25/2017, de 16 de febrero [ATC 34/2018 (Pleno), de 21 de marzo (FJ 4)]. E igual ha acontecido en el ATC 36/2018 (Pleno), de 21 de marzo, en relación con el mantenimiento de la suspensión de determinados preceptos de la Ley de Cataluña 16/2017, de 1 de agosto, de Cambio Climático, dada la «similitud intensa o coincidencia literal» con otras normas anteriores declaradas inconstitucionales y nulas [FJ $3 \mathrm{c}$ )].

Por el contrario, se descarta la aplicación del criterio del fumus boni iuris en la resolución de los incidentes sobre el mantenimiento o levantamiento de la suspensión en el ATC 29/2018 (Pleno), de 20 de marzo, respecto de la Ley de Cataluña 15/2017, de 25 de julio, de la Agencia de Ciberseguridad, pues el TC no ha declarado la inconstitucionalidad o nulidad de ninguna norma autonómica que contenga previsiones idénticas o de intensa similitud (FJ 4); en los AATC 30 y 31 (Pleno), de 20 de marzo, en relación, respectivamente, con la Ley de la Comunidad Valenciana 2/2017, de 3 de febrero, por la Función Social de la Vivienda y la Ley de Extremadura 2/2017, de 17 de febrero, de Emergencia Social de la Vivienda, dada la falta de identidad sustancial entre los preceptos cuya suspensión se pretende y los invocados como similares [ATC 30/2018, FJ 6 a)], así como por resultar suficiente para resolver los incidentes el criterio de los perjuicios de imposible o difícil reparación (ATC 31/2018, FJ 5); y en el ATC 37/2018 (Pleno), de 22 de marzo, respecto a los preceptos recurridos de la Ley de Illes Balears 9/2017, de 3 de octubre, de Regulación de las Corridas de Toros y de Protección de Animales, pues aquellos preceptos no contienen una regulación idéntica a los de la Ley de Cataluña 28/2010, de 3 de agosto, de modificación del texto refundido de la Ley de Protección de los Animales aprobado el decreto legislativo 2/2008, de 15 de abril, declarados inconstitucionales en la STC 177/2016, de 20 de octubre.

Por otra parte, el TC en el ATC 25/2018 (Pleno), de 20 de marzo, ha considerado que, como criterio excepcional, la quiebra de la seguridad jurídica constituye razón suficiente para mantener la suspensión de los preceptos impugnados de la Ley de Cataluña 10/2017, de 27 de junio, de voluntades digitales y de modificación de los libros segundo y cuarto del Código Civil, dado que en este caso la inseguridad jurídica nacería de «la mera convivencia sobre una misma realidad de regímenes jurídicos dispares y no de que actuaciones de la Administración de la Comunidad Autónoma puedan quedar en entre dicho si la resolución de fondo fuera favorable al Estado», adquiriendo 
máximo relieve el interés «derivado de la certidumbre que los ciudadanos concernidos por un ordenamiento jurídico privado han de tener respecto del régimen de aplicabilidad del mismo».

El TC ha descartado, en aplicación de la doctrina constitucional sobre la carencia de valor normativo de los preámbulos de las leyes, su idoneidad como objeto de un incidente de suspensión, así como acudir al criterio de la máxima relevancia jurídico constitucional de las cuestiones suscitadas en el proceso para decidir sobre el levantamiento o mantenimiento de la suspensión de determinados preceptos de la Ley de Cataluña 21/2017, de 20 de septiembre, de la Agencia Catalana de Protección Social, al plantearse una estricta controversia competencial, pues de recurrirse en estos supuestos a aquel criterio «se postergaría el criterio de la ponderación de los intereses concernidos y de los perjuicios que pudieran derivarse del mantenimiento o levantamiento de la suspensión» [ATC 32/2018 (Pleno), de 21 de marzo (FJ 4); también ATC 29/2018 (Pleno), de 20 de marzo, en relación con los preceptos impugnados de la Ley de Cataluña 15/2017, de 25 de julio, de la Agencia de Cibereseguridad (FJ 4)].

5. Los motivos de especial transcendencia constitucional apreciados en los recursos de amparo resueltos durante este cuatrimestre han sido los siguientes: $1^{\circ}{ }^{\circ}$ [STC 155/2009, FJ 2 a)] que el recurso plantea un problema o afecta a una faceta de un derecho fundamental sobre el que no hay doctrina del TC [SSTC 9/2018 (Sala Segunda), de 5 de febrero — garantías materiales y procesales en procedimiento administrativo sancionador-; 10/2018 (Sala Segunda), de 5 de febrero — inadmisión de solicitud de dictamen en relación con la tramitación parlamentaria de una proposición de ley_ ${ }^{5}$; 12/2018 (Pleno), de 8 de febrero — sanción disciplinaria a un profesor de educación primaria por dirigir nota a los padres de los alumnos explicando las razones por la que se adhiere a una convocatoria de huelga-; 21/2018 (Sala Primera), de 5 de marzo — falta de información suficiente sobre las razones de una detención y denegación de acceso a las actuaciones policiales esenciales —; 26/2018 (Sala Primera), de 5 de marzo — archivo de diligencias previas por denuncia de acceso indebido y revelación del contenido de mensajes de correo electrónico en una cuenta facilitada por el partido político en el que militaba el recurrente—; 35/2018 (Sala Segunda), de 23 de abril - ejecución de resolución judicial firme en matera de alimentos en favor del hijo—y 47/2018 (Pleno), de 26 de abril —admisión a trámite

5 También se apreció como motivo de especial trascendencia constitucional que el asunto suscitado transciende el caso concreto en la medida en que pudiera tener consecuencias políticas generales (STC 155/2009, FJ 2 g). 
de una iniciativa parlamentaria que supone la aplicación de normas legales anuladas o suspendidas por el TC- ${ }^{6}$ ]; 2. ${ }^{\circ}$ ) [STC 155/2009, FJ 2 b)] que el recurso puede dar ocasión al TC para aclarar o cambiar su doctrina como consecuencia de un proceso de reflexión interna [SSTC 22/2018 (Sala Primera), de 5 de marzo - inaplicación de derecho comunitario respecto de supuesto trato discriminatorio a funcionario interino por reducción de jornada de trabajo y retribuciones respecto a empleado público fijo—; 24/2018 (Sala Primera) — denegación de personación mediante abogado y procurador por no encontrase el recurrente a disposición del juez instructor en diligencias previas -; 25/2018 (Sala Segunda), de 5 de marzo — criterios sobre la prescripción del delito de blanqueo de capitales imprudente-; 36 y 37/2018 (Sala Segunda), de 23 de abril — condena en casación con valoración de pruebas personales sin la garantía de la inmediación $\left.{ }^{7}-\right]$; 3. ${ }^{\circ}$ ) [STC 155/2009, FJ 2 b)] que el recurso puede dar ocasión al TC para aclarar o cambiar su doctrina como consecuencia de cambios normativos relevantes para la configuración del derecho [STC 3/2018 (Sala Segunda), de 22 de enero - denegación por motivo de edad de reconocimiento de situación de dependencia y de atención en centro asistencial para discapacitados- $]^{8} ; 4^{\circ}$ ) [STC 155/2009, FJ 2 e)] que la doctrina del TC sobre el derecho fundamental podría estar siendo incumplida de modo general y reiterado por la jurisdicción ordinaria o pudieran existir resoluciones judiciales contradictorias sobre el derecho fundamental [STC 6/2018 (Sala Segunda), de 22 de enero -inadmisión de recurso contencioso-administrativo por no aportar los documentos exigidos a las personas jurídicas para entablar acciones-; 5. $)$ [STC 155/2009, FJ 2 f)] que el órgano judicial puede haber incurrido en una negativa manifiesta del deber de acatamiento a la doctrina de este TC [SSTC 5/2018 (Sala Segunda), de 22 de enero - emplazamiento por edictos sin agotar los medios de comunicación personal en proceso de ejecución hipotecaria—; 23/2018 (Sala Segunda), de 5 de marzo — decisión judicial

6 También se apreció como motivo de especial trascendencia constitucional que el asunto suscitado transciende el caso concreto en la medida en que pudiera tener consecuencias políticas generales (STC 155/2009, FJ 2 g).

7 En el recurso de amparo resuelto por la STC 37/2018 también se apreció como motivo de especial trascendencia constitucional que el asunto suscitado transciende el caso concreto porque plantea una cuestión jurídica de relevante y general repercusión social y económica (STC 155/2009, FJ 2 g).

8 También se apreció como motivo de especial trascendencia constitucional que el asunto suscitado transciende el caso concreto porque plantea una cuestión jurídica de relevante y general repercusión social y económica (STC 155/2009, FJ 2 g). 
fundada en el carácter exclusivamente revisor de la jurisdicción contencioso-administrativa—; 39/2018 (Sala Primera), de 23 de abril, —emplazamiento por edictos constando el domicilio del demandado en la demanda en proceso de desahucio-; 6.o [STC 155/2009, FJ 2 g)] que el asunto suscitado trasciende el caso concreto, al plantear una cuestión jurídica de relevante y general repercusión social y económica o porque pudiera tener consecuencias políticas generales ${ }^{9}$ [SSTC 3/2018 (Sala Segunda), de 22 de enero - denegación por motivo de edad de reconocimiento de situación de dependencia y de atención en centro asistencial para discapacitados-; 4/2018 (Sala Segunda), de 22 de enero —inadmisión de enmiendas a iniciativa legislativa—; 10/2018 (Sala Segunda), de 5 de febrero —inadmisión de solicitud de dictamen en relación con la tramitación parlamentaria de una proposición de ley—; 20/2018 (Sala Primera), de 5 de marzo —exclusión de un sindicato del procedimiento de designación de candidatos para la elección de miembros del consejo de administración de Radio Televisión Madrid—; 37/2018 (Sala Segunda), de 23 de abril —condena en casación con valoración de pruebas personales sin la garantía de la inmediación-; 38/2018 (Sala Primera), de 23 de abril — falta de motivación de resolución judicial sobre ultraactividad de convenio colectivo-; 46/2018 (Pleno), de 26 de abril — admisión a trámite de una iniciativa parlamentaria que supone la aplicación de una norma legal suspendida por el TC—; 47/2018 (Pleno), de 26 de abril —admisión a trámite de una iniciativa parlamentaria que supone la aplicación de normas legales anuladas o suspendidas por el TC-; ATC 40/2018 (Sección Primera), de 13 de abril — criterio aplicativo recogido en acuerdo no jurisdiccional de la Sala de lo Penal del Tribunal Supremo sobre recurso de casación contra sentencias dictadas en apelación por las audiencias provinciales y la Sala de lo Penal de la Audiencia Nacional—;

9 En el ATC 49/2018 (Pleno), de 26 de abril, que admite a trámite la impugnación promovida por el Gobierno de la Nación contra sendas resoluciones del presidente del Parlamento de Cataluña por las que, respectivamente, se propone a don Carles Puigdemont i Casamajó como candidato a presidente de la Generalitat y se convoca sesión para el debate y votación de su investidura, no se aduce expresamente ninguno de los motivos de especial transcendencia constitucional recogidos en la STC 155/2009, FJ 2 , pero se invocan las "cuestiones de interés general» que se plantean en el proceso constitucional como justificación para no declarar extinguida la impugnación como consecuencia de que el presidente de la Cámara dejara sin efecto la propuesta del don Carlos Puigdemont i Casamajó como candidato. La alusión a "cuestiones de interés general» quizás pudiera interpretarse como una implícita invocación del motivo de especial trascendencia constitucional de la STC 155/2009, FJ 2 g. 
ATC 41/2018 (Sección Primera), de 16 de abril —inadmisión de recurso de casación por infracción de normativa autonómica contra sentencias dictadas en única instancia por el Pleno de la Sala de lo Contencioso-Administrativo del Tribunal Superior de Justicia-].

Como se viene advirtiendo en crónicas anteriores, se confirma la aplicación amplia y generosa que el TC viene haciendo de los motivos de especial trascendencia constitucional referidos a que el recurso plantea un problema o afecta a la faceta de un derecho fundamental sobre el que no hay doctrina constitucional [STC 155/2009, FJ 2 a)] o que puede dar ocasión al TC a aclarar o cambiar su doctrina [STC 155/2009, FJ 2 b)]. Como revela la lectura de la mayor parte de las sentencias dictadas en este cuatrimestre, ambos motivos de especial trascendencia constitucional se han apreciado en relación con supuestos en los que no se crea nueva doctrina constitucional, ni se aclara o cambia una doctrina preexistente, sino en los que se aplica una doctrina constitucional ya sentada e, incluso, de manera consolidada, resultando que dichos supuestos, aunque algunas veces son inéditos, sin embargo en la mayoría de las ocasiones solo presentan algún o algunos elementos fácticos novedosos, dudosamente significativos para la doctrina constitucional que se aplica. Corroboran esta apreciación, entre otras, en relación con el primero de los motivos de especial trascendencia constitucional referidos las SSTC 9/2018 (Sala Segunda), de 5 de febrero; 12/2018 (Pleno), de 8 de febrero; 26/2018 (Sala Primera), de 5 de marzo; 35/2018 (Sala Segunda), de 23 de abril; y en relación con el segundo de los motivos de especial trascendencia, las SSTC 22/2018 (Sala Primera) y 25/2018 (Sala Segunda), de 5 de marzo.

Constituyen excepciones a esta actuación jurisprudencial mediante una aplicación más rigurosa de los citados motivos de especial trascendencia constitucional las SSTC 21/2018 (Sala Primera), de 5 de marzo $^{10}$, y 24/2018 (Sala Primera), de 5 de marzo ${ }^{11}$, en las que además se identifica la concreta faceta novedosa del derecho fundamental sobre la que no existe doctrina específica de este Tribunal (STC 21/2018, FJ 3), o la doctrina constitucional, con cita de las sentencias en las que está recogida, que procede cambiar o aclarar (STC 24/2018, FJ 2). Parece conveniente la generalización de este proceder en orden a una aplicación más precisa de los motivos de especial trascendencia constitucional.

De otra parte, se consolida el criterio según el cual deviene manifiesta la renuencia judicial del deber de acatamiento a la jurisprudencia constitucional, vinculante para todos los órganos judiciales (art. $5.1 \mathrm{LOPJ}$ ), en aquellos

10 Véase infra p. 32-33.

11 Véase infra p. 36-37. 
supuestos en los que, a pesar de que el justiciable invoca la infracción de una determinada doctrina constitucional, llegando incluso a aportar copia de resoluciones de este TC, el órgano judicial omite toda consideración sobre la dimensión constitucional de las alegaciones de la parte, máxime si tal elusión acontece en el seno de un incidente de nulidad de actuaciones [SSTC 5/2018 (Sala Segunda), de 22 de enero, FJ 2; 39/2018 (Sala Primera), de 23 de abril, FJ 2].

6. En fin, por lo que respecta a la especial transcendencia constitucional de los recursos de amparo parlamentarios, doctrina que se extiende a los recursos de amparo electorales, el ATC 47/2018 (Sección Primera), de 25 de abril, declara que si bien la particularidad que presentan los primeros - inexistencia de una vía judicial previa (art. 42 LOTC) y su repercusión sobre el ejercicio de la función representativa y el derecho de los ciudadanos a participar en los asuntos públicos a través de representantes - los sitúa «en una posición especial a la hora de determinar su dimensión objetiva al valorar la especial transcendencia constitucional», ello no significa, ni tal conclusión puede alcanzarse de las resoluciones de este TC, que «todos los recursos de amparo parlamentarios gocen en sí mismos de especial trascendencia constitucional por su naturaleza o en atención a los derechos que puedan verse afectados» (FJ 3). Se argumenta al respecto en el citado auto que la propia STC 155/2009 especificó que «eran determinados amparos electorales o parlamentarios - no todos- los que podrían tener unas consecuencias políticas generales que los hicieran acreedores de apreciar en ellos la especial transcendencia constitucional que justificaría su admisión a trámite. Más dicha posibilidad ha de ser justificada, contrastada y constatada caso a caso, en función de la concreta pretensión planteada y también en atención a la existencia de jurisprudencia constitucional que haya abordado las cuestiones jurídicas formuladas en cada recurso" (ibid.).

Precisamente, el TC entiende que las cuestiones jurídicas planteadas en el concreto supuesto considerado - indebida e insuficiente motivación de las decisiones de la Mesa de la Diputación Permanente de la Asamblea de Madrid que inadmitieron la solicitud de comparecencia ante una comisión de investigación de quienes habían sido altos cargos del gobierno de la nación-, relativas a la competencia de control que los reglamentos de las Cámaras atribuyen a sus órganos rectores sobre las iniciativas parlamentarias, «han sido objeto de una abundante, específica y coherente doctrina expresada en la jurisprudencia constitucional», cuyo contenido «no ha variado desde sus pronunciamientos iniciales [....] y ha sido reiterada más recientemente [...] en un conjunto de sentencias que se refieren, precisamente, a diversas decisiones adoptadas en el seno de la Asamblea de Madrid». Así pues, el TC ya se ha pronunciado sobre 
las cuestiones jurídicas que plantea la demanda, sin que el caso suscitado "permita a este Tribunal profundizar, aclarar o complementar su doctrina sobre la cuestión objetiva sometida a su valoración». En consecuencia, la Sección desestima el recurso de súplica interpuesto por el Ministerio Fiscal contra la providencia que había inadmitido el recurso de amparo por carecer de especial transcendencia constitucional (FJ 3).

7. En la STC 12/2018 (Pleno), de 8 de febrero ${ }^{12}$, resulta cuanto menos sorprendente el orden en el que el TC decide examinar las vulneraciones de derechos fundamentales invocadas en la demanda de amparo. Frente a lo que es práctica común inveterada en la materia, en la sentencia no se comienza por enjuiciar la denunciada infracción de la libertad de expresión [art. 20.1.a) CE] y del derecho de huelga (art. 28.1 CE), por la imposición de una sanción disciplinaria a un profesor que dirigió una nota a los padres de los alumnos explicándoles las razones por las que se adhería a la convocatoria de una huelga, sino la lesión del principio de legalidad en materia sancionadora (art. 25.1 $\mathrm{CE}$ ), con la consecuencia de que, al concluir que la conducta del recurrente no tiene encaje en los tipos sancionadores aplicados por la Administración y prosperar, por consiguiente, la vulneración del derecho a la legalidad sancionadora, «no procede el análisis — se afirma en la sentencia — de las demás quejas aducidas en la demanda» [FJ 4 b)]. La condición de la libertad de expresión y del derecho de huelga como causas excluyentes de la antijuridicidad de la conducta sancionada parece requerir inicialmente el examen, de acuerdo con una reiterada doctrina constitucional, de si dicha conducta constituye, en sí misma considerada, lícito ejercicio de aquella libertad y de este derecho y, en consecuencia, está amparada por ellos y no puede, por lo tanto, ser objeto de sanción. Solo una vez descartado que la conducta controvertida esté amparada por la libertad de expresión y/o el derecho huelga procedería analizar la correcta subsunción de la misma en los tipos sancionadores aplicados desde la perspectiva del principio de legalidad (art. 25.1 CE).

8. Por su parte, la STC 38/2018 (Sala Primera), de 23 de abril, acuerda en su parte dispositiva «inadmitir el recurso de amparo», una vez apreciada la concurrencia de un motivo de especial transcendencia constitucional (FJ 2) y descartada, a continuación, tras su enjuiciamiento de fondo, la denunciada vulneración del derecho fundamental invocado en la demanda. En lugar de acordar la desestimación del recurso de amparo, como viene siendo costumbre en fase de sentencia cuando se concluye que no existe la lesión del derecho

12 Véase infra pp. 274-276. 
fundamental en la que se sustenta la pretensión de amparo, la Sala considera que «el recurso de amparo debió ser inadmitido», afirmación que únicamente puede entenderse referida a la ya precluida fase de admisión del recurso de amparo (art. 50.1 LOTC), decisión que en este caso se adopta, sin embargo, al dictar la sentencia (FJ 5).

9. En relación con el alcance de los efectos del otorgamiento del amparo, la STC 4/2018 (Sala Segunda), de 22 de enero ${ }^{13}$, que estima, por lesión del derecho al ejercicio de las funciones representativas (art. 23.2 CE), el recurso interpuesto contra las decisiones de inadmisión de determinadas enmiendas a una iniciativa legislativa contrae los efectos del otorgamiento del amparo a la declaración de nulidad de las decisiones impugnadas, descartando la extensión de esta declaración a los preceptos legales vigentes que fueron objeto de las citadas enmiendas y que forman parte ya de la ley aprobada por la Cámara (FJ 8) ${ }^{14}$.

\section{FUENTES DEL DERECHO}

1. En la STC 42/2018 (Pleno), de 26 de abril, que resuelve el recurso de inconstitucionalidad interpuesto por más de cincuenta diputados contra diversos preceptos legales que reforman la Ley canaria 6/2002, de 12 de junio, sobre medidas de ordenación territorial de la actividad turística en las islas de El Hierro, La Gomera y La Palma, el TC descarta la alegada infracción del principio de jerarquía normativa (art. 9.3 CE), basada en que, según los recurrentes, la reforma impugnada vendría a situar los instrumentos de planificación singular turística a los que se refiere la disposición adicional primera por encima de las previsiones de la legislación canaria, alterando así el sistema de fuentes. La STC 42/2018 [FJ 5.c)] rechaza tal argumento, pues los instrumentos de planificación discutidos no se aprueban y ejecutan al margen del especifico régimen insular diseñado en la ley 6/2002, sino que se insertan en dicho régimen: es el propio legislador canario el que regula la cuestión de manera que no se da la sustracción a los mandatos del planeamiento territorial por parte de la autoridad administrativa; los citados instrumentos de planificación se someten a la legislación canaria en la materia, sin que pueda ser excepcionada su aplicación ni prescindir de las determinaciones de la ley habilitante.

Por el contrario, en aplicación de la doctrina sobre las leyes singulares, la STC 42/2018 (FJ 6) declara inconstitucional y nulo el precepto legal por el

13 Véase infra pp. 269-270.

14 Juan Carlos Duque Villanueva. 
que se declaran de interés insular a los efectos de la tramitación de instrumentos de planificación singular turística determinadas actuaciones urbanísticas, algunas de las cuales estarían afectadas por una previa sentencia firme de la Sala de lo Contencioso-Administrativo. El TC descarta que se trate de un supuesto de ley autoaplicativa, ya que «la norma no es autosuficiente, en cuanto que requiere de posteriores actos de aplicación contemplados por el propio precepto». Tampoco se trataría de una ley de destinatario único o de estructura singular en atención a los destinatarios a los que va dirigida, pues «la identidad de los destinatarios de la disposición cuestionada no ha sido tenida en cuenta como factor determinante del contenido de su regulación ni constituye en sí un dato obvio o que se aprecie con su simple lectura». Para el TC nos encontramos en realidad ante una ley singular, en cuanto que se refiere a unos concretos proyectos perfectamente identificados que fueron objeto, en su momento, de regulación por el plan territorial anulado por el Tribunal Supremo. Alcanzada esta conclusión, el TC procede a aplicar el canon de enjuiciamiento establecido en su doctrina para esta categoría de leyes singulares, lo que exige examinar si el supuesto de hecho que contempla la norma cuestionada tiene una justificación objetiva y, de ser así, si la utilización de la ley es proporcionada a la excepcionalidad que se trata de atender y que ha justificado su aprobación; además, ha de verificarse su incidencia en el derecho a la tutela judicial efectiva, en cuanto pueda impedir el acceso al control judicial de derechos e intereses legítimos afectados y eliminar la posibilidad de un control judicial de la misma intensidad que hubieran podido realizar los tribunales de la jurisdicción contencioso-administrativa. El resultado de ese análisis es que el TC no aprecia que concurra en este caso «un interés de relevancia constitucional que exija inexcusablemente la aprobación de una norma con rango de ley»; tampoco advierte que se cumpla la exigencia de proporcionalidad, pues «el legislador no ha explicitado las razones por las que entiende que la utilización de la ley es una medida razonable y proporcionada, teniendo en cuenta, además, que la utilización de la ley elimina el control de la jurisdicción contencioso-administrativa en relación con la declaración de interés insular de concretas actuaciones», lo cual implica a su vez que la disposición cuestionada ha vulnerado el art. 24.1 CE, «al impedir el acceso al control judicial de derechos e intereses legítimos afectados y eliminar la posibilidad de un control judicial de la misma intensidad que hubieran podido realizar los Tribunales de la jurisdicción contencioso-administrativa».

2. Del problema de las leyes singulares se ocupa también la STC $45 / 2018$ (Pleno), de 26 de abril, que estima una cuestión de inconstitucionalidad promovida respecto de una disposición contenida en una Ley de Presupuestos 
Generales del Estado que suprimió del derecho a una pensión excepcional del régimen de clases pasivas del Estado (previamente reconocida por una norma con rango de ley). Se trata, por tanto, de una ley singular que adopta una medida expropiatoria, y más concretamente, de una «ley expropiatoria autoaplicativa», como modalidad de las leyes singulares, lo que lleva a la STC 45/2018 (FJ 4) a una exposición un tanto confusa sobre el canon de enjuiciamiento aplicable. Con todo, el TC acaba precisando que, al tratarse de una ley expropiatoria singular, en razón de la materia sobre la que recae, está en todo caso sometida a las garantías del art. 33.3 CE, la primera de las cuales es la causa expropiandi, de suerte que lo que resulta determinante para que una expropiación legislativa singular pueda considerarse conforme con la Constitución es la concurrencia de una causa de utilidad pública o interés social: solo esta dota de justificación objetiva a la medida expropiatoria.

En el caso enjuiciado, el TC concluye apreciando que en la disposición cuestionada no concurre la finalidad de utilidad pública o interés social que ha de legitimar cualquier medida de naturaleza expropiatoria, lo que conduce a declararla inconstitucional y nula. Ello es así porque la genérica remisión de la disposición cuestionada a «las circunstancias puestas de relieve» por la sentencia del orden penal que invoca no justifica una finalidad de utilidad pública o interés social (esa sentencia no condenó a la pérdida de la pensión reconocida; apreció, sí, una falsedad documental de la beneficiaria, pero desconectada de la prueba presentada en el expediente administrativo tramitado en su día a efectos del reconocimiento de la pensión excepcional). Y la exposición de motivos de Ley de Presupuestos en que se inserta esa disposición tampoco proporciona explicación alguna que permita vislumbrar la concurrencia de una finalidad de utilidad pública o interés social.

3. La STC 13/2018 (Pleno), de 8 de febrero ${ }^{15}$, estima la cuestión prejudicial de validez planteada y declara inconstitucional y nula la norma foral fiscal cuestionada, que suprime, en el impuesto sobre transmisiones patrimoniales y actos jurídicos documentados, la exención aplicable a la Iglesia católica y las iglesias, confesiones y comunidades religiosas que tengan suscritos acuerdos de cooperación con el Estado español, en relación con los bienes destinados a actividades religiosas y asistenciales. El TC considera, partiendo de la doctrina sentada en la STC 207/2013 (Pleno), de 5 de noviembre, que la supresión de esa exención vulnera la competencia estatal para regular las condiciones básicas para el ejercicio, en términos de igualdad (art. 149.1.1 CE), del derecho a la libertad religiosa y de culto, en este caso en su dimensión colectiva (art. 16.3

15 Véase también infra pp. 254-255. 
CE, en relación con el art. 7.2 de la Ley Orgánica 7/1980, de Libertad Religiosa, y los preceptos concordantes de las leyes reguladoras de los acuerdos de cooperación suscritos entre el Estado español y las iglesias, confesiones y comunidades religiosas inscritas).

Lo relevante de la STC 13/2018 a efectos del sistema de fuentes del derecho, que es lo que ahora nos interesa, atañe a la reafirmación por el TC de su doctrina sobre la determinación del ámbito objetivo de la cuestión prejudicial de validez, sentada en la STC (Pleno) 118/2016, de 23 de junio [FJ 3 c) $]^{16}$. En efecto, la STC 13/2018 [FJ 1 c)] se considera en la necesidad de precisar, de oficio (acaso influida por el reciente pronunciamiento del ATC 150/2017, de 14 de noviembre $)^{17}$ que la norma foral cuestionada es susceptible de ser controlada por la jurisdicción constitucional mediante la cuestión prejudicial de validez, por tratarse de una norma foral "fiscal» que además se dirige a mantener, establecer y regular, dentro del territorio foral, el régimen tributario, atendiendo a la estructura general impositiva del Estado.

4. De nuevo sobre el efecto vinculante de las directivas de la Unión Europea conforme han sido interpretadas por el Tribunal de Justicia de la Unión Europea (TJUE) se pronuncia el TC en la STC 22/2018 (Sala Primera), de 5 de marzo ${ }^{18}$, que considera que la sentencia impugnada en amparo lesionó el derecho a la tutela judicial efectiva del recurrente, funcionario interino, porque el órgano judicial desestimó su pretensión de reclamación de cantidades dejadas de percibir por reducción de jornada sin tomar en consideración la jurisprudencia del TJUE (aplicada también por el Tribunal Supremo) sobre la proscripción de diferencias de trato entre empleados públicos fijos y temporales.

Tras recordar una vez más que el derecho de la Unión Europea no es canon de constitucionalidad, la STC 22/2018 (FJ 4) declara que la ausencia de razonamiento judicial sobre la incidencia en el caso de esa jurisprudencia del TJUE impide al TC valorar la racionalidad de la respuesta judicial «y poder así descartar que se haya producido, en el caso concreto, una preterición o desconocimiento del Derecho de la Unión Europea que, desde el punto de vista del artículo $24 \mathrm{CE}$, pudiera suponer una selección irrazonable o arbitraria de la norma aplicable al proceso» ${ }^{19}$. Estamos pues ante un

16 Reseñada en REDC, núm. 108, 2016, pp. 241 y 235-237.

17 Reseñado en $R E D C$, núm. 112, 2018, pp. 235-236.

18 Véase infra pp. 273-274.

19 En su voto concurrente conjunto, los magistrados Balaguer Callejón y Conde-Pumpido Tourón consideran que la vulneración del derecho a la tutela judicial efectiva no 
pronunciamiento que sigue la pauta de otros anteriores sobre la posición del TC como garante del principio de primacía del derecho de la Unión Europea, al menos en el marco del proceso constitucional de amparo ${ }^{20}$.

\section{ESTRUCTURA TERRITORIAL DEL ESTADO}

1. La STC $14 / 2018$ (Pleno), de 20 de febrero ${ }^{21}$, es doctrinalmente una de las más relevantes del período comentado, pues afirma realizar una sistematización de la doctrina general del TC sobre el modelo constitucional de controles del Estado sobre las entidades locales y las comunidades autónomas.

Subraya el TC que a diferencia de lo que ocurre en el caso de los entes locales, la Constitución sí ha regulado las competencias de las comunidades autónomas (arts. 147 a 151 y disposición adicional primera) y los controles que respecto de su desarrollo puede ejercer el Estado (arts. 150.2, 155 y 161.2). Por eso la autonomía de las comunidades autónomas (arts. 2, 137 y 156 CE y estatutos de autonomía) impide como regla general una regulación legal de controles administrativos distintos de los constitucionalmente previstos.

Sin embargo, prosigue el TC, la autonomía de las comunidades autónomas no llega a excluir toda intervención de la Administración general del Estado sobre las comunidades autónomas que no esté específicamente prevista en la Constitución.

En efecto, para el TC, tal tipo de intervención puede darse también en el caso de las competencias estatales de coordinación en determinadas materias, que suponen la capacidad de regular y ejercer facultades que implican un «cierto poder de dirección» sobre algunos ámbitos de actividad autonómica, «consecuencia de la posición de superioridad en que se encuentra el que coordina respecto al coordinado"; un poder que, en todo caso, debe respetar la garantía constitucional de la autonomía de las comunidades autónomas, que, naturalmente, es más cualificada que la de los entes locales.

se ha producido propiamente porque el órgano judicial dejara de pronunciarse sobre el alegato sustancial del recurrente referido a la prohibición de diferencias de trato entre empleados públicos fijos y temporales conforme a las directivas europeas, sino por vulnerar el principio de primacía del derecho de la Unión Europea; el órgano judicial solo podía o bien aplicar esas directivas ya interpretadas con carácter vinculante por el TJUE, o bien plantear ante este la correspondiente cuestión prejudicial.

20 Herminio Losada González.

$21 \quad$ Véase también supra p. 233. 
Así, la STC 14/2018 considera que a la vista de la doctrina constitucional, cabe concluir que los límites a la configuración legislativa de mecanismos de coordinación o control administrativo cambian según que la instancia territorial coordinada o controlada sea un ente local o una comunidad autónoma.

En el primer caso, los arts. 137, 140 y $141 \mathrm{CE}$ operan como un canon de ponderación conforme al que la regulación es legítima si la intensidad de la intervención es tendencialmente correlativa a la de los intereses supralocales involucrados [STC 107/2017, de 21 de septiembre, FJ 3 c), y las allí citadas].

En el segundo caso, los arts. 2, 137 y $156 \mathrm{CE}$ así como las competencias estatutarias de las comunidades autónomas operan, con carácter general, como una prohibición de controles distintos de los constitucionalmente previstos. No obstante, aquellas previsiones constitucionales y estatutarias pueden llegar a admitir la regulación legal de técnicas que hallen cobertura en una competencia estatal de coordinación y resulten debidas, necesarias y proporcionadas, en el sentido de que sean la alternativa menos restrictiva para salvaguardar bienes legítimos y produzcan más beneficios en estos que perjuicios en la autonomía de las comunidades autónomas.

Se introduce, así, por el TC en la determinación de los límites a la configuración legislativa de mecanismos de coordinación o control administrativo el principio de proporcionalidad como herramienta fundamental para realizar aquella.

Para ilustrar la doctrina sistematizada, cita la STC 14/2018 algunas modalidades de intervención ya admitidas por la jurisprudencia constitucional en marcos competenciales y escenarios diversos como son $1 .{ }^{\circ}$ ) la aprobación de planes hidrológicos elaborados o revisados por las comunidades autónomas, como instrumento de coordinación, sin admitir el control sustitutivo consistente en la actuación subsidiaria del Gobierno [STC 227/1988, de 29 de noviembre, FJ 20 d)]; 2. ${ }^{\circ}$ ) la imposición de la elaboración de un plan económico-financiero y su remisión al Consejo de Política Fiscal y Financiera de las comunidades autónomas a fin de comprobar la idoneidad de las medidas programadas al objetivo de estabilidad presupuestaria, que se traduce en un requerimiento a aquella para que lleve a cabo su reformulación (STC 134/2011, de 20 de julio, FJ 10); 3. ${ }^{\circ}$ ) las intervenciones reguladas en la Ley Orgánica 2/2012, de 27 de abril, de Estabilidad Presupuestaria y Sostenibilidad Financiera [SSTC 215/2014, de 18 de diciembre, FFJJ 2 b) y 7 a); y 101/2016, de 25 de mayo, FJ 6], en particular la emisión de propuestas (que han de considerarse no vinculantes), en cuanto constituyen una injerencia legítima por "debida», "necesaria» y "no desproporcionada» al «incumplimiento, deliberado o negligente», de las 
obligaciones constitucionales de estabilidad presupuestaria [STC 215/2014, FJ 7 a)]; o 4.o) la retención de recursos del sistema de financiación a fin de satisfacer las deudas contraídas por la comunidad autónoma con sus proveedores, tras constatar el incumplimiento persistente del plan autonómico de tesorería y efectuar sin éxito varios requerimientos, valorada como una medida que no contradice el principio de proporcionalidad, ni supone la fórmula más gravosa para la consecución del fin perseguido (STC 101/2016, FFJJ 2, 6 y 11).

Así, recuerda el TC que el ejercicio de la intervención por el Estado fundado en sus competencias de coordinación no puede suponer una sustitución en la definición autonómica de sus propias políticas en el ámbito de su competencia. En este sentido, la doctrina del TC traza el límite de lo constitucionalmente admisible en la necesaria preservación de la definición de las políticas autonómicas, pues si a los órganos estatales «se les habilitara para formular en positivo las medidas a aplicar y, además, éstas fuesen ejecutivas por su sola autoridad, resulta claro que se estaría sustituyendo a la Comunidad Autónoma de que se trate en la configuración de qué políticas deben desarrollarse en ámbitos de su competencia».

De acuerdo con la STC 14/2018, el principio de autonomía impone otros dos límites a la configuración legislativa de mecanismos de coordinación o control, comunes para los entes locales y las comunidades autónomas.

En primer lugar, la intervención administrativa ha de estar suficientemente objetivada o determinada en normas de rango legal.

En segundo lugar, el previo

requerimiento es un presupuesto necesario de todo control administrativo por sustitución que arraiga directamente en la garantía constitucional de la autonomía local. No es constitucionalmente aceptable que la Administración autonómica ocupe ámbitos competenciales que el legislador ha atribuido ordinariamente al municipio para la tutela de los intereses de su comunidad territorial, si antes no le da la oportunidad de cumplir sus obligaciones en un plazo razonable y, por tanto, de corregir por sí las disfunciones verificadas. Dicho de otro modo: la ley debe definir suficientemente los presupuestos materiales y procedimentales del control y, en particular, las garantías que permitan al ente local evitar la subrogación mediante el cumplimiento autónomo de sus competencias [STC 154/2015, de 9 de julio, FJ 7 c)].

Naturalmente, la exigencia de requerimiento previo, encerrada en la garantía constitucional de la autonomía local, ha de estarlo también en las garantías competenciales y de autonomía de las comunidades autónomas. 
Destaca la STC 14/2018 que la jurisprudencia recaída hasta ahora en materia de alta inspección educativa constituye una manifestación específica de la referida doctrina general sobre el modelo constitucional de controles del Estado sobre las comunidades autónomas, lo que le lleva a concluir que en el caso concreto que se resolvía, el modo en que ha sido diseñado el procedimiento regulado en los tres últimos párrafos del apdo. c) de la disposición adicional trigésima octava.4 de la Ley Orgánica 2/2006, de 3 de mayo, de Educación (LOE) ${ }^{22}$ no supera el juicio de constitucionalidad, porque ni se compadece con los límites específicamente marcados por este TC a la competencia estatal sobre la alta inspección ni cumple ninguna de las dos exigencias comunes que se desprenden de la doctrina general sobre controles.

Para el TC, si bien corresponde al Estado velar por el respeto de los derechos lingüísticos en el sistema educativo, tal función ha de desplegarse sin desbordar las competencias que constitucionalmente le están reservadas y sin soslayar los límites y exigencias que ha fijado la jurisprudencia constitucional. Al no hacerlo así, los tres últimos párrafos de la disposición adicional trigésima octava.4 c) LOE, incorporada por el art. único.99 de la Ley Orgánica 8/2013, de 9 de diciembre, para la Mejora de la Calidad Educativa (LOMCE), son declarados inconstitucionales y nulos.

2. El principio de proporcionalidad aplicado en un ámbito, el competencial, que no es su ámbito natural tradicional, el de los derechos fundamentales, reaparece en la STC 8/2018 (Pleno), de 25 de enero, en la que se resuelve un

22 Así, se impugnan aquellos párrafos que, tras determinar que «los padres, madres o tutores legales tendrán derecho a que sus hijos o pupilos reciban enseńanza en castellano", arbitran un sistema que, esencialmente, se caracteriza por lo siguiente: (i) si la programación anual de la Administración educativa competente no garantizase oferta docente razonable sostenida con fondos públicos en la que el castellano sea utilizado como lengua vehicular, el Ministerio de Educación, Cultura y Deporte asumirá íntegramente, por cuenta de la Administración educativa correspondiente, los gastos efectivos de escolarización en centros privados, que repercutirá a dicha Administración educativa; (ii) la comprobación del supuesto de hecho que determina el nacimiento de esta obligación financiera corresponde al Ministerio de Educación, Cultura y Deporte, a través de un procedimiento iniciado a instancia del interesado, instruido por la Alta Inspección de Educación, y en el que deberá darse audiencia a la Administración educativa afectada; y (iii) la obligación financiera tendrá carácter excepcional y se extinguirá con la adopción por la Administración educativa competente de medidas adecuadas para garantizar los derechos lingüísticos individuales, sin que se consideren adecuadas a este propósito las medidas que supongan la atención individualizada en castellano o la separación en grupos por razón de la lengua habitual. 
recurso de inconstitucionalidad interpuesto por el presidente del Gobierno contra determinados preceptos de la Ley de la Comunidad Autónoma del País Vasco 6/2015, de 30 de junio, de medidas adicionales de protección medioambiental para la extracción de hidrocarburos no convencionales y la fractura hidráulica.

El TC recuerda que el Estado, con fundamento en sus competencias en materia de economía (art. 149.1.13 CE) y bases del régimen minero (art. 149.1.25 $\mathrm{CE}$ ), ha permitido el empleo de la técnica de la fractura hidráulica en el art. 9.5 de la Ley 34/1998, de 7 de octubre, del Sector de Hidrocarburos (LSH).

Ello supone que, de acuerdo con la doctrina previa, las comunidades autónomas no puedan prohibir de manera absoluta e incondicionada el empleo de esta técnica de la fractura hidráulica al amparo de sus competencias en materia de sanidad, de ordenación del territorio o de medio ambiente, pues las competencias autonómicas estatutariamente atribuidas, aún de forma exclusiva, no autorizan a desconocer las competencias que, con el mismo carácter de exclusivas, vienen reservadas al Estado por virtud del art. 149.1 CE. Así, señala el TC que el Estado, al ejercer sus títulos competenciales, puede lícitamente condicionar la competencia de las comunidades autónomas.

Recuerda el TC que la competencia autonómica para establecer normas adicionales de protección del medio ambiente permite a las comunidades autónomas imponer «requisitos y cargas para el otorgamiento de autorizaciones y concesiones no previstos por la legislación estatal»; ahora bien, siempre que tales exigencias sean «razonables y proporcionadas al fin propuesto» y no «alter[en] el ordenamiento básico en materia de régimen minero y energético».

Reaparece en este punto el principio de proporcionalidad como herramienta para resolver cuestiones de distribución competencial. Ciertamente, su utilización puede ser aceptable en aquellos concretos supuestos en los que la determinación de ámbitos competenciales no se establece constitucionalmente a través de reglas sino de principios, como es por ejemplo la fijación de un contenido competencial que preserve la autonomía local (STC 41/2016, de 3 de marzo); o la determinación del grado de intervención del Estado en el ámbito competencial autonómico cuando aquel dispone de competencias de coordinación (STC 14/2018). Cabría incluso plantearse si el principio de proporcionalidad es un instrumento adecuado para tratar de restringir la utilización por el Estado de determinados títulos horizontales, pues tanto en este supuesto como en el supuesto de las competencias de coordinación cabe sostener que la proporcionalidad puede llegar a ser un mecanismo de acomodación o integración de dos competencias, estatal y autonómica, que están llamadas a cohonestarse. Sin embargo, un uso indiscriminado del principio de proporcionalidad para resolver las controversias competenciales puede 
acabar convirtiendo el sistema de distribución de competencias en un sistema demasiado casuístico en el que no existan reglas sino únicamente principios que deban ser acomodados en cada caso.

Sea como fuere, la STC 8/2018 declara la inconstitucionalidad del art. 3 de la ley 6/2015 que dispone la prohibición del empleo del fracking en los «terrenos clasificados como suelo no urbanizable cuando pueda tener efectos negativos sobre las características geológicas, ambientales, paisajísticas o socioeconómicas de la zona, o en relación con otros ámbitos competenciales de la Comunidad Autónoma vasca, en función de lo que establezcan los instrumentos de ordenación territorial, urbanística y/o ambiental».

La remisión a «lo que establezcan los instrumentos de ordenación territorial urbanística y/o ambiental» se considera por el TC que no es suficiente para evitar la falta de «determinación precisa de requisitos razonables y proporcionados al fin de protección medioambiental» en la propia norma.

La STC 8/2018 considera, sin embargo, conforme con la Constitución el art. 5 de la ley $6 / 2015$, que prohíbe el uso de la técnica de la fractura hidráulica en aquellos espacios clasificados como de riesgo de vulnerabilidad media, alta o muy alta en el mapa de vulnerabilidad a la contaminación de los acuíferos de la comunidad autónoma.

Para el TC el precepto contiene una norma claramente tuitiva del medio ambiente compatible con las bases medioambientales estatales, pero además compatible con las bases del régimen minero y energético del art. 149.1.25 $\mathrm{CE}$, pues recuerda el TC que entre los límites de esta clase de normas autonómicas de protección medioambientales con incidencia en las normas sobre explotación y aprovechamiento de recursos mineros y energéticos, en concreto el art. 9.5 LSH, estaría «el establecimiento de prohibiciones genéricas, absolutas e incondicionadas" [SSTC 106/2014, de 24 de junio, FJ 8 a), y 73/2016, de 14 de abril, FJ 8].

En el caso del precepto vasco la limitación de la superficie en que rige la prohibición, representa, afirma el TC, el $37 \%$ del territorio de la Comunidad Autónoma del País Vasco, lo que impide equiparar este supuesto a las prohibiciones generales sobre todo el territorio de la comunidad autónoma. Y la prohibición tampoco puede ser calificada de genérica e incondicionada puesto que parte de una previa evaluación de cada uno de los acuíferos por la comunidad autónoma y ciñe la proscripción de la técnica del fracking a los que hayan ya sido declarados con un grado de vulnerabilidad media, alta o muy alta de contaminación (no la extiende, por tanto, a los de vulnerabilidad baja o muy baja).

Al aplicar el principio de proporcionalidad el TC acaba afirmando que la norma objeto de recurso no puede ser considerada irrazonable ni 
desproporcionada en relación con el fin propuesto, pues la prohibición autonómica recurrida tiende a proteger un recurso esencial del medio ambiente, el agua (un recurso «vital» con una influencia decisiva, afirma el TC, sobre la vida humana, animal y vegetal), cuyas características pueden hacer que se multipliquen exponencialmente y sean irreversibles los efectos contaminantes que, no habiéndose previsto en la evaluación de impacto ambiental, incluso por insuficiencia de los conocimientos técnicos, pudieran no obstante producirse.

3. La STC 7/2018 (Pleno), de 25 de enero, resuelve un recurso de inconstitucionalidad interpuesto por más de cincuenta diputados del Grupo Parlamentario Popular en el Congreso de los Diputados contra diversos preceptos de la Ley 22/2010, de 20 de julio, del Código de Consumo de Cataluña. La sentencia viene a ratificar dos interpretaciones recientes del propio TC, la del art. 38 CE y la del art. 139.2 CE, que son muy relevantes desde el punto de vista de la estructura territorial del Estado y que ya quedaron reflejadas en una crónica anterior ${ }^{23}$.

Así, en efecto, en primer lugar, ratifica aquella doctrina por la cual se considera que la libertad de empresa reconocida en el art. 38 garantiza —además de la adecuación de las restricciones públicas al ejercicio de la actividad económica a la promoción de un objetivo constitucionalmente legítimo - la igualdad de limitaciones de la actividad económica para las empresas de una misma clase ante cada ordenamiento individualmente considerado, el estatal y los autonómicos. Así, recuerda el TC que no es posible considerar que del derecho a la libertad de empresa se derive la exigencia de que las concretas condiciones de ejercicio de la actividad económica tengan que ser las mismas en todo el territorio nacional, pues la potestad legislativa de la que las comunidades autónomas gozan potencialmente da a nuestro ordenamiento una estructura compuesta, por obra de la cual puede ser distinta la posición jurídica de los ciudadanos en las distintas partes del territorio nacional.

Así, y frente a una doctrina mantenida por el propio TC en el pasado [por ejemplo en la STC 109/2003, de 5 de junio, (FJ 8)], se afirma ahora que del art. $38 \mathrm{CE}$ no cabe derivar la garantía de que todas las empresas de un mismo sector disfruten del mismo grado de libertad en todo el territorio nacional, sino que únicamente cabe derivar la garantía de que todas las empresas de un mismo sector disfruten del mismo grado de libertad ante cada ordenamiento individualmente considerado, el estatal y los autonómicos.

23 Véase REDC, núm. 112, 2018, pp. 260-263. 
La STC 7/2018, ratifica, en segundo lugar, aquella reciente interpretación dada al alcance del art. 139.2 CE por la STC 111/2017, de 5 de octubre, y que supone acomodarse a la interpretación que de preceptos similares se ha venido dando en otros ordenamientos de nuestro entorno como es el caso del alcance dado a la denominada "cláusula de comercio durmiente» por la doctrina del Tribunal Supremo de los Estados Unidos o del alcance dado a las libertades básicas del mercado interior por la doctrina mayoritaria del Tribunal de Justicia de la Unión Europea. Así, en efecto, de acuerdo con la doctrina del TC, el art. 139.2 CE proscribe

las regulaciones o medidas de signo proteccionista; esto es, que dificultan injustificadamente en un territorio la comercialización de productos de otras zonas o el ejercicio de actividades empresariales por parte de personas procedentes de otros lugares. Consecuentemente, bajo el prisma del artículo 139.2 CE, cobra relevancia una única modalidad de límite o condición a la libertad empresarial: la que favorece a productos u operadores de un territorio en detrimento de los de otros lugares.

Tal doctrina supone que la imposición realizada por uno de los preceptos impugnados a aquellos operadores económicos que actúan en Cataluña de la obligación de proporcionar determinados documentos e informaciones escritas en lengua catalana cuando así lo solicite el consumidor no tiene el resultado específico adicional de tener un efecto restrictivo más oneroso, de hecho o de derecho, sobre el ejercicio de la actividad económica de los operadores económicos provenientes de fuera de la comunidad autónoma que sobre el ejercicio de la actividad económica de los operadores económicos tradicionalmente residentes en aquella. El precepto impugnado supone la imposición de un coste suplementario a todos aquellos operadores que actúan en Cataluńa, independientemente de su procedencia, pues el precepto les impone el deber de tener a disposición de los consumidores toda una serie de documentos e informaciones escritas también en lengua catalana. Al no tener la regulación efectos diferenciados más onerosos sobre los operadores foráneos que sobre los operadores locales, no se da el presupuesto para someterla al control de su justificación bajo el parámetro del art. 139.2 CE. Otra cosa es que el TC la someta, como efectivamente hace la STC 7/2018, al control de su justificación bajo la más laxa comprobación de su razonabilidad en aplicación del canon del art. 38 $\mathrm{CE}$, pues a pesar de que la medida no tiene efectos diferenciados sobre los distintos operadores económicos, sí tiene efectos restrictivos generales sobre la actividad económica. 
4. La STC 13/2008 (Pleno), de 8 de febrero ${ }^{24}$, considera vulnerada la competencia del Estado para regular las condiciones básicas que garantizan la igualdad en el ejercicio de los derechos (art. 149.1.1 CE). La sentencia resuelve una cuestión prejudicial de validez promovida por el Tribunal Superior de Justicia del País Vasco, en relación con el art. 4.2 de la Norma Foral de las Juntas Generales de Gipuzkoa 13/2012, de 27 de diciembre, por la que se aprueban determinadas modificaciones tributarias, por posible vulneración de los arts. 16.3, 139.1 y 149.1.1 CE.

El precepto autonómico impugnado suprime la exención que hasta entonces venía siendo aplicable en el impuesto sobre transmisiones patrimoniales y actos jurídicos documentados a los bienes y derechos destinados «a actividades religiosas o asistenciales».

La STC 13/2018 concluye que el precepto foral se opone a lo dispuesto en el art. 11.3 C) del anexo de la Ley 26/1992, de 10 de noviembre, por la que se aprueba el acuerdo de cooperación del Estado con la Comisión Islámica de España, y que declara expresamente exentas del impuesto sobre transmisiones patrimoniales y actos jurídicos documentados tanto a la Comisión Islámica de Espańa como a las comunidades que la integran, «siempre que los respectivos bienes o derechos adquiridos se destinen a actividades religiosas o asistenciales». La norma de contraste es la referida, pues en el proceso a quo se trataba de una comunidad musulmana de Elgoibar, que había adquirido un local con la finalidad de adaptarlo para el culto musulmán.

El TC recuerda que el Real Decreto Legislativo 1/1993, de 24 de septiembre, por el que se aprueba el texto refundido de la Ley del Impuesto sobre Transmisiones Patrimoniales y Actos Jurídicos Documentados (LITP) en la letra d) del apdo. A) del art. 45.I, acoge una exención subjetiva total en el impuesto sobre transmisiones patrimoniales y actos jurídicos documentados (en las transmisiones patrimoniales onerosas, en las operaciones societarias y en los actos jurídicos documentados) para las comunidades religiosas que tengan suscritos acuerdos de cooperación con el Estado español. La Ley 26/1992 por la que se aprueba el acuerdo de cooperación del Estado con la Comisión Islámica objetiva tal exención, al limitarla exclusivamente a los bienes o derechos adquiridos que se destinen «a actividades religiosas o asistenciales» [art. 11.3 C) del anexo de la ley 26/1992].

La Norma Foral 13/2012, al eliminar la exención anteriormente prevista en la letra d) del apdo. A) del núm. 1 del art. 41 de la Norma Foral de las Juntas Generales de Gipuzkoa 18/1987, de 30 de diciembre, se separa de lo

24 Véase también supra pp. 244-245. 
señalado en el art. 11.3 C) del anexo de la Ley 26/1992, y también de lo establecido en la letra d) del apdo. A) del art. 45.I LITP.

El TC rechaza que el problema planteado quede solo circunscrito a concretar si los territorios históricos pueden o no establecer en los tributos concertados una exención diferente a la prevista en la normativa tributaria estatal, pues lo discutido trasciende del ámbito material del concierto económico para alcanzar también al contenido de un derecho fundamental, como es la libertad religiosa.

Ello supone que la cuestión es si con la decisión de supresión de la exención controvertida se ha afectado a las condiciones básicas en el ejercicio del derecho fundamental a la libertad religiosa (art. 149.1.1, en conexión con el art. 16, ambos CE).

Para el TC el precepto autonómico vulnera la competencia exclusiva del Estado prevista en el art. 149.1.1 CE, en relación con el art. 16.3 CE, y consecuentemente se declara la inconstitucionalidad y nulidad del art. 4.2 de la Norma Foral de las Juntas Generales de Gipuzkoa 13/2012, en la medida en que deja sin contenido la letra d) del apdo. A) del núm. 1 del art. 41 de la Norma Foral de las Juntas Generales de Gipuzkoa 18/1987, de 30 de diciembre, del impuesto sobre transmisiones patrimoniales y actos jurídicos documentados.

5. La STC 15/2018 (Pleno), de 22 de febrero, consiente, con una argumentación cuando menos controvertida, la centralización de funciones ejecutivas en materia de medio ambiente. Materia sobre la que las competencias de ejecución, junto con las competencias de desarrollo de lo básico, corresponden en principio a las comunidades autónomas. La sentencia resuelve un conflicto positivo de competencias planteado por el Gobierno de la Generalitat contra determinados preceptos del Real Decreto 1494/2011, de 24 de octubre, por el que se regula el fondo de carbono para una economía sostenible.

El real decreto impugnado regula un fondo que está dotado con las aportaciones que anualmente se consignan en los presupuestos generales del Estado, y que tiene entre sus fines impulsar la actividad de las empresas en los sectores asociados a la lucha contra el cambio climático mediante la adquisición por el Estado de créditos de carbono.

Denuncia la Generalidad que el funcionamiento del fondo responde a criterios totalmente centralizados, tanto en cuanto a la toma de las decisiones como a su gestión, lo que vulnera las competencias autonómicas de desarrollo normativo y de concreción de objetivos básicos así como las competencias de ejecución en materia de medio ambiente.

La STC 15/2018, tras encuadrar efectivamente la controversia competencial en la materia medioambiental a la que se refiere el art. 149.1.23 CE, 
considera, frente a la alegación de la recurrente, que la atribución al Consejo Rector por el art. 7 del real decreto de la función de determinación de las prioridades del fondo para la adquisición de reducciones verificadas de emisiones supone la atribución al Estado de una competencia ejecutiva y no de una normativa, por lo que lo que el TC debe valorar si existe justificación constitucional para que el legislador haya reservado al Estado las competencias ejecutivas o si, por el contario, vulnera el orden competencial atribuir la decisión de adquisición de créditos de carbono y la gestión del fondo a sus órganos de gobierno.

La STC 15/2018 considera que la priorización de los sectores y actuaciones en relación con los cuales se pueden adquirir estos créditos requiere proceder a complejas valoraciones de oportunidad, eficacia, viabilidad técnica y económica. Igualmente, seńala que la capacidad de los proyectos para promover actividad económica hipocarbónica, en aras de la consecución del primer fin del fondo, rebasa el ámbito territorial de una comunidad autónoma.

No desconoce el TC, pues la STC 15/2018 así lo recuerda, que la utilización de la supraterritorialidad como criterio determinante para la atribución o el traslado de la titularidad de competencias al Estado en ámbitos, en principio, reservados a las competencias autonómicas tiene, según la doctrina constitucional, carácter excepcional, de manera que solo podrá tener lugar cuando no quepa establecer ningún punto de conexión que permita el ejercicio de las competencias autonómicas o cuando además del carácter supraautonómico del fenómeno objeto de la competencia, no sea posible el fraccionamiento de la actividad pública ejercida sobre él y, aun en este caso, siempre que dicha actuación tampoco pueda ejercerse mediante mecanismos de cooperación o de coordinación $y$, por ello, requiera un grado de homogeneidad que solo pueda garantizar su atribución a un único titular, forzosamente el Estado, y cuando sea necesario recurrir a un ente supraordenado con capacidad de integrar intereses contrapuestos de sus componentes parciales, sin olvidar el peligro inminente de daños irreparables, que nos sitúa en el terreno del estado de necesidad.

Pero la STC 15/2018 considera que concurren las condiciones que justifican con carácter excepcional la gestión centralizada del fondo, pues afirma que

es evidente que la consecución de los objetivos del fondo requiere que todos los proyectos que en Espańa puedan optar a la venta de créditos de carbono, concurran en un proceso de valoración en el que se garantice la adecuada aplicación, en términos homogéneos, de los criterios establecidos en el artículo 7 del Real Decreto. La decisión de adquisición de créditos de carbono demanda una valoración homogénea de todos los posibles proyectos con independencia de su 
potencial ubicación, y, en definitiva, por un único órgano con capacidad de integrar intereses contrapuestos, de cara a seleccionar la compra de aquellos que mejor respondan a los criterios de eficiencia e innovación establecidos en el artículo 7.4 .

En fin, señala el TC que una eventual previa territorialización de los fondos asignados a la compra de estos créditos determinaría inevitablemente la consecuencia de que en algunas comunidades autónomas quedaran proyectos que no podrían beneficiarse de esta posibilidad por haberse agotado en ella los fondos asignados, mientras que en otras quedaran fondos excedentes por no haberse presentado proyectos que reunieran las condiciones exigidas para su adquisición en la correspondiente convocatoria.

La argumentación referida que supone fundarse en el carácter competitivo del proceso de compra de los créditos para justificar su centralización contrasta fuertemente con aquella otra del TC que en supuestos similares ha considerado que a la hora de determinar, en este caso, la compra de créditos de carbono no serían alegables posibles dificultades previas en la determinación de los concretos proyectos, que pueden solucionarse con diversas técnicas, comenzando con

una planificación que determine el tipo de proyectos que deba ser objeto de la actuación estratégica. La información que al respecto posea el Estado, junto con la proveniente de las Comunidades Autónomas, permite alcanzar criterios objetivos para distribuir territorialmente los fondos presupuestarios, con lo cual no tienen por qué producirse quiebras relevantes en la garantía de alcanzarse las mismas posibilidades de obtención, [en aquel caso] de la subvención en todo el territorio nacional. En segundo lugar, mediante el establecimiento de mecanismos de cooperación y coordinación, a través de los cuales puede garantizarse la eficacia de las medidas que constituyen el objeto del Plan.

También ha dicho el TC que el argumento del agotamiento de los fondos no resulta determinante, puesto que "pueden arbitrarse sistemas de cooperación que posibiliten el desplazamiento de los fondos» (SSTC 95/2016, de 12 de mayo, FJ 5 o 100/2017, de 20 de julio, FJ 6).

Así, frente a lo afirmado por la STC 15/2018 cabe considerar que la necesidad de realizar una valoración global de los diferentes proyectos que concurren no puede justificar la asunción de competencias ejecutivas por el Estado y el correlativo desplazamiento de las autonómicas, pues este aspecto puede ser solventado mediante el uso de técnicas de coordinación que permitan el acceso a la información necesaria. 
La STC 15/2018 orilla, por tanto y una vez más, aquella doctrina que considera que la garantía de la eficacia de la normativa estatal ha de cohonestarse con el respeto al principio de autonomía, de modo que las dificultades que pudieran existir no pueden ser alegadas para eludir competencias que constitucionalmente correspondan a una comunidad autónoma.

$\mathrm{Al}$ respecto ha de tenerse en cuenta que el TC ha venido sosteniendo que las competencias legislativas básicas que el art. 149.1 CE le atribuye al Estado le permitirían fijar los puntos de conexión que estimase oportunos para determinar la comunidad autónoma a la que en cada caso correspondería ejercer los actos ejecutivos, y en tal escenario, podría también establecer técnicas de coordinación, tanto de naturaleza vertical —entre el Estado y las comunidades autónomas-, como de naturaleza horizontal —entre comunidades autónomas-, mediante las que favorecer el control relativo al cumplimiento de los requisitos exigidos para tener derecho al reconocimiento y mantenimiento de las ayudas económicas. Tales instrumentos posibilitarían resolver posibles conflictos, haciendo innecesario que la función ejecutiva se asigne a un único titular.

Como se viene comprobando a lo largo de las presentes crónicas es cada vez más frecuente que el TC admita la centralización de actuaciones ejecutivas, lo que supone convertir lo que debería ser algo excepcional en general. Se distorsiona así el modelo de distribución de competencias con el consiguiente riesgo de perder la más mínima certidumbre.

6. Las SSTC 40 y 41/2018 (Pleno), de 26 de abril, resuelven sendos recursos de inconstitucionalidad presentados por el presidente del Gobierno contra dos normas autonómicas: la Ley Foral 14/2007, de 4 de abril, del Patrimonio de Navarra y la Ley 5/2011, de 10 de marzo, del Patrimonio de Aragón —a la que se le añade la impugnación del texto refundido de la Ley de patrimonio de Aragón, aprobado por Decreto Legislativo 4/2013, de 17 de diciembre-.

Los preceptos impugnados de la norma navarra prevén la atribución a la Comunidad Foral de Navarra de los inmuebles vacantes «situados en su territorio» (art. 15) y de los «saldos y depósitos abandonados» en «entidades financieras sitas en Navarra» (art. 16).

Los preceptos impugnados de la norma aragonesa prevén la atribución a la Comunidad Autónoma de Aragón de las fincas que reemplacen a las parcelas cuyo dueño no fuese conocido durante un proceso de concentración parcelaria (disposición adicional sexta).

El recurrente entiende que las normas autonómicas exceden de las competencias estatutarias para la conservación, modificación y desarrollo del derecho civil propio y vulneran con ello la competencia exclusiva del Estado sobre legislación civil ex art. 149.1.8 CE. Asimismo, subraya que ambas normas 
autonómicas entran en directa contradicción con el art. 17 de la Ley 33/2003, de 3 de noviembre, del Patrimonio de las Administraciones Públicas, dictado al amparo de la competencia estatal prevista en el art. 149.1.8 CE (según expresa la disposición final segunda.2 de la propia ley 33/2003), en cuanto atribuye la titularidad de los mismos bienes al Estado

Las SSTC 40 y 41/2018 encuadran los preceptos cuestionados en el ámbito material del derecho civil en cuanto regulan la forma de adquirir la propiedad.

El TC desestima los recursos en cuanto observa la concurrencia de conexión suficiente entre las figuras de los inmuebles vacantes y de los depósitos y saldos abandonados con la figura de los bienes vacantes abintestatos, estos últimos regulados tanto en la Compilación del Derecho civil Foral de Navarra como en la Compilación del Derecho civil aragonés. Así, afirma el TC que tanto las figuras de los inmuebles vacantes y de los depósitos y saldos abandonados como la figura de los bienes vacantes abintestatos no dejan de pertenecer a una misma clase o institución, que es la de los bienes abandonados y sin dueño conocido. Existe, por tanto, según el TC, una relación entre la atribución de los bienes mostrencos y el derecho propio foral que legitima constitucionalmente su regulación por las respectivas comunidades autónomas, pues no puede considerarse ajena o desvinculada del derecho civil foral, sino más bien como una norma que se incardina en su derecho patrimonial. En definitiva, existiendo dos clases de bienes vacantes, los que no tienen dueño conocido y los que aun teniéndolo dejan de tenerlo por haber fallecido su titular sin herederos testamentarios o intestados, las compilaciones respectivas regulan este segundo tipo de bienes vacantes, lo que implica una conexión con el primer tipo y justifica, de acuerdo con la doctrina constitucional de la conectividad, la competencia autonómica de desarrollo de su derecho en materia civil.

Recordemos que de acuerdo con la doctrina constitucional cabe que las comunidades autónomas dotadas de derecho civil foral o especial regulen instituciones conexas con las ya reguladas en la compilación dentro de una actualización o innovación de los contenidos de ésta según los principios informadores peculiares del derecho foral.

Para las SSTC 40 y 41/2018, con la regulación de la adquisición de bienes inmuebles vacantes y saldos y depósitos abandonados el legislador autonómico respectivo está desarrollando el derecho foral existente.

El voto particular firmado por cinco magistrados ${ }^{25}$ considera que no cabe apreciar la concurrencia de la necesaria conexión que exige la doctrina

25 Formuló voto particular discrepante a la sentencia el magistrado González-Trevijano Sánchez, al que se adhirieron los magistrados Ollero Tassara, Narváez Rodríguez, Montoya Melgar y Enríquez Sancho. 
constitucional entre la sucesión intestada a favor de la respectiva comunidad autónoma con los inmuebles vacantes y los depósitos y saldos abandonados. Los magistrados discrepantes entienden que son instituciones de diferente naturaleza que se desenvuelven en contextos distintos.

La sucesión abintestato es una institución típica del derecho sucesorio según la cual, a falta de voluntad manifestada en testamento, es la norma la que dispone los sucesivos llamamientos en favor de los herederos del causante, dado que este falleció sin disponer lo oportuno sobre sus bienes. La noción misma de abintestato reclama la existencia de un titular, aunque no haya dispuesto nada respecto a ese concreto bien.

En cambio, la atribución de los bienes inmuebles vacantes se relaciona con su condición de abandonados, esto es, que carecen de dueño porque no lo han tenido nunca o por el abandono o renuncia de su anterior propietario. Es el hecho de que el inmueble carezca de dueño conocido lo que pone en marcha la adquisición legal del dominio y su posterior incorporación al patrimonio.

De acuerdo con el voto particular la regulación del abintestato responde a la necesidad de cerrar el sistema sucesorio autonómico. Se trata de una cláusula de cierre para evitar, precisamente, la vacancia indefinida de los bienes y preservar de este modo la seguridad jurídica, impidiendo el abandono de los bienes a disposición del primer ocupante. Con ello se evita tanto que las herencias queden vacantes como la exclusión del tráfico jurídico de los bienes que integran esas herencias. Por el contrario, la regla atributiva de la titularidad de los vacantes en favor del Estado es la consecuencia jurídica de su abandono, que extingue el derecho de su titular sobre los mismos y los convierte, por consiguiente, en res nullius, susceptibles de apropiación.

Sea como fuere, lo que es evidente es que el TC parece haber seguido en las dos sentencias comentadas una senda distinta a la que siguió, con el apoyo de los magistrados que ahora se encuentran en la minoría, en la reciente STC 133/2017, de 16 de noviembre ${ }^{26}$, en donde estimó el recurso de inconstitucionalidad promovido frente a diversos preceptos de la ley gallega que regulaba las instituciones de la adopción y la autotutela al considerar que no tenían conexión con instituciones forales preexistentes.

En efecto, en aquella ocasión el TC consideró que no concurría la necesaria conexión entre la regulación de la adopción que se contenía en la ley impugnada y las diferentes instituciones consuetudinarias gallegas alegadas. Instituciones como el prohijamiento (afillamento), la perfiliación (perfilatio), la casa y la compañía familiar, institutos todos ellos disciplinados en normas integrantes del ordenamiento civil gallego, pero que se consideraron por el

26 Reseńada en REDC, núm. 112, 2018, p. 263. 
TC que tenían una finalidad distinta pues se dirigían al mantenimiento y continuidad de las pequeñas explotaciones agrícolas.

Parece que las SSTC 40 y 41/2018 retornarían a aquella otra senda transitada por la STC 95/2017, de 6 de julio, en la que se reconoció la competencia de Cataluña para regular las figuras jurídicas de la propiedad temporal y la propiedad compartida por su conexión con instituciones como la enfiteusis y la sustitución fideicomisaria, conexión que, por cierto, los magistrados discrepantes de la STC 133/2017 —que en las aquí comentadas SSTC 40 y 41/2018 vuelven a estar en la mayoría - habían denunciado que en absoluto era más fuerte que la que presentaban las instituciones de la adopción y la autotutela con determinadas figuras tradicionales del derecho gallego ${ }^{27}$.

\section{ORGANIZACIÓN DE LOS PODERES PÚBLICOS}

1. De interés resulta la STC 34/2018 (Pleno), de 12 de abril ${ }^{28}$, que resuelve el conflicto de órganos constitucionales trabado entre el Gobierno y la Mesa del Congreso de los Diputados en torno al alcance del veto presupuestario del Gobierno previsto en el art. 134.6 CE. La doctrina sentada en la STC 34/2018 se reitera en la STC 44/2018 (Pleno), de 26 de abril.

El fracaso de la investidura del presidente del Gobierno tras los resultados electorales de 20 de diciembre de 2015 supuso una legislatura fallida, con un Gobierno en funciones de prolongada duración que se negó a someterse al control parlamentario, lo que dio lugar a la formulación por el Congreso de los Diputados de un conflicto entre órganos constitucionales del Estado (arts. 73 a 75 LOTC), que se encuentra pendiente de resolución por el Tribunal Constitucional. La investidura "convulsa» ${ }^{29}$ del presidente del Gobierno tras la celebración de nuevas elecciones generales el 26 de junio de 2016 ha dado lugar a la actual legislatura, caracterizada por una situación política de debilidad parlamentara del Gobierno ${ }^{30}$, que ha hecho frecuente uso del veto presupuestario previsto en el art. 134.6 CE para intentar paralizar iniciativas legislativas de la oposición; también en este caso el

27 Tomás de la Quadra-Salcedo Janini.

28 Véase también supra pp. 4-5.

29 Así la califica M. Aragón, en su estudio «Legislatura fallida e investidura convulsa. Análisis y consecuencias», REDC, núm. 109, 2017, pp. 15-34.

30 La investidura de un nuevo presidente del Gobierno tras la moción de censura celebrada los días 31 de mayo y 1 de junio de 2018 ha dado paso a un Gobierno cuya estabilidad parlamentaria tampoco parece asegurada. 
Congreso ha reaccionado mediante la interposición de sendos conflictos entre poderes del Estado, resueltos por el TC a favor del Congreso en las citadas SSTC 34/2018 y 44/2018.

De esta suerte, la compleja situación política derivada del desgaste del sistema bipartidista ha provocado que un proceso constitucional de escasa trascendencia práctica (en treinta y ocho años de jurisprudencia constitucional el TC dictó únicamente dos sentencias resolviendo conflictos entre órganos constitucionales del Estado: STC 45/1986, de 17 de abril, y 234/2000, de 3 de octubre) cobre mayor protagonismo (en un solo mes el TC ha dictado dos nuevas sentencias y es previsible que dicte próximamente una tercera, en relación con el problema de la negativa del Gobierno en funciones a someterse al control parlamentario del Congreso), lo que acaso no sea del todo deseable, pues los cauces políticos propios del sistema parlamentario deberían ser suficientes para solucionar los conflictos entre poderes del Estado, manteniendo el proceso constitucional de los arts. 73 a 75 LOTC su carácter residual.

La STC 34/2018 desestima el conflicto planteado por el Gobierno contra el Congreso de los Diputados, en relación con el veto presupuestario opuesto por aquel a la tramitación de una proposición de ley de la oposición referida a la suspensión del calendario de implantación de la Ley Orgánica 8/2013, de 9 de diciembre, para la Mejora de la Calidad Educativa. La Mesa del Congreso rechazó el veto del Gobierno a la tramitación parlamentaria de esa iniciativa legislativa, por entender que el Gobierno no justificó de manera objetiva y suficiente que la misma implique aumento de créditos o disminución de ingresos de los presupuestos en vigor.

La STC 34/2018 (FJ 3) precisa que la controversia suscitada se refiere al menoscabo de una competencia del Gobierno, lo que constituye objeto idóneo del conflicto regulado en los arts. 73 a 75 LOTC, que no solo alcanza a supuestos de invasión de competencias, sino también de menoscabo (como ya había declarado la STC 234/2000, corrigiendo el inicial criterio restricto de la STC 45/1986). Por lo que atañe al fondo del asunto, el TC, partiendo de la doctrina constitucional sobre el reparto de competencias presupuestarias entre el poder ejecutivo y el poder legislativo en nuestro sistema parlamentario, que se refleja en el art. $134 \mathrm{CE}$ (STC 34/2018, FJ 6), determina el alcance de la potestad de veto del Gobierno a la que se refiere el art. 134.6 CE, seńalando sus límites: i) solo puede afectar a iniciativas legislativas que «incidan directamente sobre el Presupuesto aprobado", esto es, sobre "los gastos e ingresos del sector público estatal» (art. 134.2 CE), porque «suponga aumento de los créditos o disminución de los ingresos presupuestarios» (arts. 134.6 $\mathrm{CE}$ ); ii), esa incidencia presupuestaria debe ser «real y efectiva» (no meramente estimativa o hipotética) y, además, debe referirse al presupuesto en 
vigor, no a presupuestos futuros; iii) el Gobierno, que dispone de un amplio margen de apreciación en su estimación de si la iniciativa legislativa en cuestión afecta, y en qué medida, a los ingresos y gastos del presupuesto, cuando decida oponer su veto debe hacerlo de manera motivada (arts. 126.2 y 3 del Reglamento del Congreso de los Diputados), "precisando adecuadamente los concretos créditos que se verían directamente afectados, de entre los contenidos en el presupuesto en vigor» (FJ 7).

Por su parte, la Mesa del Congreso no está vinculada automáticamente por el veto del Gobierno. En efecto, la Mesa está facultada para pronunciarse «sobre el carácter manifiestamente infundado del criterio del Gobierno, siempre y cuando resulte evidente, a la luz de la propia motivación aportada por este, que no se ha justificado la afectación de la iniciativa a los ingresos y gastos contenidos en el propio presupuesto que, en cada ejercicio, cumple la función instrumental a la propia acción de Gobierno». Esta función de la Mesa «tiene en todo caso carácter jurídico-técnico, no respondiendo en ningún caso a criterios de oportunidad política». En suma, la Mesa, sin sustituir la apreciación del Gobierno, puede rechazar el veto cuando compruebe que el Gobierno no ha justificado que la iniciativa legislativa que pretende vetar afecta de forma real y efectiva a los presupuestos en vigor, en forma de disminución de los ingresos o de aumento de los créditos presupuestarios (FJ 7).

En fin, en cuanto al control constitucional posible en este tipo de conflictos, se advierte que el TC no puede sustituir ni la apreciación del Gobierno acerca de la afectación al presupuesto, ni tampoco la calificación de la medida que lleva a cabo la Mesa de la Cámara; tan solo le corresponde determinar si el rechazo al veto del Gobierno ha producido el menoscabo de la competencia que a este le otorga el art. 134.6 CE, para lo cual resulta necesario examinar tanto la motivación exteriorizada por el Gobierno al invocar la potestad del art. 134.6 CE como la expresada por la resolución de la Mesa del Congreso que rechaza el veto (FJ 8).

Proyectada esta doctrina al concreto supuesto enjuiciado, el TC concluye que el rechazo por la Mesa del Congreso al veto presupuestario del Gobierno a la tramitación de la proposición de ley referida a la suspensión del calendario de implantación de la Ley Orgánica 8/2013, para la Mejora de la Calidad Educativa, no ha menoscabado la competencia que al Gobierno le atribuye el art. 134.6 CE. Es así porque este no explicitó de qué manera habrían resultado afectados los presupuestos en vigor, sino que se limitó a plantear un escenario hipotético, que dependía de las decisiones que las instituciones europeas pudieran adoptar en el futuro, todo ello en referencia a la posible pérdida de aportaciones del Fondo Social Europeo relacionadas con programas ligados a la implantación de la Ley Orgánica para la Mejora de la Calidad Educativa. 
Por consiguiente, la apreciación de la Mesa de la Cámara, en el sentido de considerar que la motivación del Gobierno resulta insuficiente para verificar la «efectiva conexión» de la iniciativa legislativa con los ingresos y los gastos públicos del presupuesto en vigor, no supuso en este caso el menoscabo de la competencia del poder ejecutivo (FJ 9).

La doctrina sentada en la STC 34/2018 se reitera, como ya se anticipó, en la STC 44/2018, que resuelve otro conflicto entre el Gobierno y la Mesa del Congreso de los Diputados sobre el veto presupuestario del art. 134.6 CE, en esta ocasión en relación con una proposición de ley sobre modificación del art. 42.1 del Estatuto de los Trabajadores, para garantizar la igualdad en las condiciones laborales de los trabajadores subcontratados. El TC desestima también en este caso el conflicto planteado por el Gobierno contra la Mesa del Congreso, que rechazó el veto presupuestario a la tramitación parlamentaria de la iniciativa legislativa por entender que el Gobierno no justificó de manera objetiva y suficiente que la misma implique aumento de créditos o disminución de ingresos de los presupuestos en vigor. Considera el TC que el rechazo por la Mesa de la Cámara al veto presupuestario del Gobierno no ha menoscabado la competencia que al Gobierno le atribuye el art. 134.6 CE, pues la motivación del Gobierno para justificar su criterio no cumple la exigencia de precisar adecuadamente las concretas partidas presupuestarias del presupuesto en vigor que se verían directamente afectadas por esa iniciativa legislativa, al haberse limitado a aportar una estimación de impacto económico, insuficiente a estos efectos ${ }^{31}$.

\section{DERECHOS FUNDAMENTALES}

1. El primer cuatrimestre de 2018 ha sido especialmente productivo por lo que se refiere a pronunciamientos del TC en materia de derechos fundamentales. Debido al elevado número de sentencias dictadas, se ha intentado comentar las más interesantes, debiendo advertir al lector que se ha tratado de dar cuenta de tales pronunciamientos sin poder dedicar, por la naturaleza del presente trabajo, un estudio de los asuntos como sin duda merecerían.

2. Sobre el art. 14 CE, destaca la STC 3/2018 (Sala Segunda), de 22 de enero, que otorgó el amparo solicitado al considerar el TC que la denegación de la ayuda solicitada por el recurrente - exclusivamente por motivos de edad- vulneró su derecho a no ser discriminado. El demandante tenía

31 Herminio Losada González. 
reconocida por la Administración competente un $60 \%$ de minusvalía psíquica. La resolución administrativa impugnada, si bien le reconoció el grado de dependencia solicitado conforme a la ley, negó el tratamiento de servicio residencial para personas con discapacidad por una única razón: haber rebasado la edad de 60 ańos establecida en el art. 3 de la Orden 1363/1997, de 24 de junio. Considera el TC que la mencionada decisión se adoptó prescindiendo de toda valoración médica acerca de su estado y de las necesidades de tratamiento especializado. Dicho con otras palabras: no se le denegó la asistencia residencial para personas con discapacidad "porque no la necesitase, sino porque estaba excluido por razón de edad». Constata el TC que la citada orden no contiene ni en su breve preámbulo ni en ningún inciso de su articulado justificación alguna a esta regla de exclusión por edad. Explica la sentencia que, en todo caso, otra norma de superior rango, la Ley 11/2003, de 27 de marzo, de Servicios Sociales de la Comunidad de Madrid, permite en su art. 20.1 la continuidad de los servicios sociales que venían disfrutando quienes pasen de una etapa a otra (0-18 años; $18-65$ años; más de 65 años). Ni la Ley 11/2003 citada, como tampoco la Orden 625/2010, de 21 de abril, de la Comunidad de Madrid por la que se regulan los procedimientos para el reconocimiento de la situación de dependencia y para la elaboración del Programa Individual de Atención, dictada en desarrollo y ejecución de las previsiones de la Ley 39/2006, de 14 de diciembre, de promoción de la autonomía personal y atención a las personas en situación de dependencia, que resultaba de aplicación al caso, contienen una regla de exclusión por edad, planteando antes bien un modelo flexible que, si bien se vertebra por sectores de edad, no impide la prestación del tratamiento que requiera la persona necesitada por pasar de un grupo a otro. Por tanto, considera el TC que existían normas jurídicas autonómicas de mayor rango y de fecha posterior al cuestionado art. 3 de la Orden 1363/1997, que podían haber sido aplicadas en su lugar pese a no estar esta última derogada, evitando así la privación del derecho a la asistencia sanitaria debida que aquella traía consigo. En definitiva, estima el TC que el problema planteado no se centra tanto en la inconstitucionalidad del citado apartado del art. 3 de la Orden 1363/1997, el cual desde luego prima facie resulta contrario al art. $14 \mathrm{CE}$, sino en la negativa de las resoluciones impugnadas en evitar la aplicación de aquella norma de exclusión, pese a disponer de instrumentos jurídicos suficientes para que tal aplicación no tuviera lugar. Tal actuación lesionó el derecho del recurrente a no padecer discriminación por razón de edad.

En la STC 20/2018 (Sala Primera), de 5 de marzo, la sentencia se centraba en determinar si los acuerdos de la Mesa de la Asamblea de Madrid vulneraron los derechos de la Federación Regional de Servicios de la Unión 
General de Trabajadores-Madrid (FES-UGT) a la interdicción de la arbitrariedad de los poderes públicos, a la igualdad en la aplicación de la ley, art. 14 $\mathrm{CE}$, a acceder a los medios de comunicación social dependientes del Estado o de cualquier ente público, y a la libertad sindical, art. 28.1 CE. Consideraba la parte recurrente que los acuerdos recurridos le habrían excluido sin motivación del procedimiento de designación de candidatos para la elección de los cinco miembros del consejo de administración de Radio Televisión Madrid. Parte el TC de contextualizar la función de la Mesa de la Cámara que se incardina, sin lugar a dudas, dentro de la función de control parlamentario de los medios de comunicación social, que encuentran reflejo constitucional expreso en el art. 20.3 CE. Por tanto, considera el TC que la lectura armonizada del art. 1, en sus apdos. primero y segundo CE, y del art. 20.3 CE permite deducir que el control parlamentario que se exige de los medios de comunicación social dependientes de las administraciones públicas es un control cualificado sobre un ente público que no solo articula un servicio público de interés social manifiesto, sino que gestiona medios de comunicación que han de ser calificados como vehículo esencial de información y participación política de los ciudadanos. El art. 14 de la Ley 8/2015, de 28 de diciembre, de Radio Televisión Madrid, regula, de acuerdo con el mandato contenido en el art. 20.3 CE, que «los miembros del consejo de administración serán elegidos por la Asamblea de Madrid de entre los propuestos por los Grupos parlamentarios y las organizaciones profesionales y sociales más representativas del sector de la comunicación», y que «la Asamblea de Madrid decidirá el sistema de elección de las organizaciones profesionales y sociales que participarán en el proceso de elección del consejo de administración», de donde se desprende que la ley concede a la Cámara legislativa la potestad de establecer los criterios que habrán de regir en el proceso de selección de las organizaciones profesionales y sociales con derecho a proponer candidatos. En consecuencia, y de conformidad con lo dispuesto en el citado artículo, la Mesa de la Diputación Permanente de la Cámara aprobó «las normas reguladoras del procedimiento de elección del consejo de administración, Director General y Consejo asesor de Radio Televisión Madrid». De esta regulación se deduce, considera el TC, que la selección de las candidaturas, encargadas de proponer a la Cámara los nombres de las personas candidatas a integrar el Consejo de Administración de la radio televisión pública autonómica, no es un acto de elección puramente política, anclado en el sistema de mayorías y minorías y sin necesidad de mayor grado de motivación ${ }^{32}$. Recuerda que la federación demandante de

32 Los criterios contenidos en las normas exigen de la comisión que motive, cuando menos, si en las candidaturas seleccionadas concurre el criterio de representatividad 
amparo presentó su candidatura y, una vez aportada la documentación acreditativa del cumplimiento de los requisitos exigidos por la convocatoria, la Mesa dio traslado de la misma a la Comisión de Control del ente público Radio Televisión Madrid. La comisión parlamentaria analizó la documentación presentada, y sometió a votación las distintas candidaturas presentadas, que fueron cuatro, elevando posteriormente a la Mesa el acuerdo adoptado, que excluía únicamente a la recurrente en amparo. De la dicción literal del acuerdo no es posible extraer los motivos por los que la Comisión de Control del ente público excluyó a la FES-UGT Madrid del procedimiento de elección de los miembros del Consejo de Administración. Las razones de dicha exclusión tampoco se desprenden del acta de la reunión. Esta falta de motivación resulta especialmente relevante toda vez que FES-UGT Madrid reunía los requisitos exigidos en la convocatoria y se daba la circunstancia de que existían más puestos a cubrir que candidaturas presentadas, siendo la única asociación descartada en esta fase del procedimiento. Considera el TC que los acuerdos parlamentarios impugnados afectan al derecho de la organización recurrente a acceder en condiciones de igualdad a los medios de comunicación social de naturaleza pública, garantizada en el art. 20.3 CE. Argumentos reforzados por la naturaleza de sindicato de la federación recurrente, condición que no puede ser obviada, afirma el TC.

Sin duda, un comentario destacado merece la STC 31/2018 (Pleno), de 10 de abril, sobre la denominada educación diferenciada, que resuelve un recurso de inconstitucionalidad frente a la Ley Orgánica 8/2013, de 9 de diciembre, para la Mejora de la Calidad Educativa. La naturaleza de esta crónica impide analizar la sentencia con la profundidad que se merecería, por ello, simplemente se apuntan los aspectos principales. Los recurrentes consideraban que la normativa impugnada vulnera el derecho a la igualdad, art. 14 $\mathrm{CE}$, en relación con el derecho a la educación, art. $27 \mathrm{CE}$, al prever la educación diferenciada por sexos. Sin embargo, el TC consideró que la educación diferenciada por sexos es un modelo educativo que, en sí mismo, no causa discriminación; entiende que consiste en un método pedagógico y que forma parte del derecho del centro privado a establecer su ideario o carácter propio, y no puede ser considerado contrario a la Constitución siempre y cuando respete los derechos fundamentales y los principios constitucionales. El TC

de las asociaciones, que exige valorar «el número de afiliados, su memoria de actividades y la relevancia de los medios y/o profesionales a los que representan", y, en sentido contrario, por qué las candidaturas excluidas no cumplen esos mismos criterios, o no los cumplen en medida equivalente a las candidaturas que hubieran sido retenidas. 
analiza los tratados internacionales y el derecho comparado, además, obviamente, de la Constitución y llega a la conclusión, aun con cuatro votos particulares discrepantes, de que se trata de un modelo pedagógico que la dirección de cada centro puede o no adoptar libremente y que, con la misma libertad, pueden o no elegir los padres para sus hijos. Por tanto, forma parte del «derecho al ideario o carácter propio del centro», derecho que forma parte de la libertad de enseńanza. El derecho al ideario propio tiene límites y, según afirma la sentencia, «no sería aceptable si tiene un contenido incompatible por sí mismo con los derechos fundamentales» o si, sin llegar a vulnerarlos, incumple la obligación, derivada del art. 27.2 CE, de que la educación prestada en el centro «tenga por objeto el pleno desarrollo de la personalidad humana en el respeto a los principios democráticos de convivencia, y a los derechos y libertades fundamentales en su concreta plasmación constitucional, pues éstos han de inspirar cualquier modelo educativo, público o privado». Según los recurrentes, la educación diferenciada por sexos conlleva «un riesgo muy alto» de que uno de los grupos sea considerado inferior al otro. El TC rechaza esta afirmación y señala que en este caso está fuera de toda duda su constitucionalidad: niños y niñas, al margen del modelo pedagógico que elijan sus padres, tienen garantizado un puesto escolar; asimismo, ni la programación de las enseñanzas (que corresponde a los poderes públicos, tal y como establece el art. 27.5 CE), ni la forma de prestación de las mismas cambia en función de si el centro es mixto, femenino o masculino. En el caso de producirse diferencias de trato vedadas constitucionalmente, no pueden atribuirse a la ley ni al modelo en sí, sino que serían imputables al concreto centro escolar. En este sentido, la sentencia considera suficiente la medida que la ley prevé en su art. 83.4, que impone a los centros de educación diferenciada, y solo a estos, la obligación de «exponer en su proyecto educativo las razones educativas de la elección de dicho sistema, así como las medidas académicas que desarrollan para favorecer la igualdad».

3. En la STC 21/2018 (Sala Primera), de 5 de marzo ${ }^{33}$, el demandante de amparo alegaba que durante el desarrollo de la detención policial fueron vulnerados sus derechos fundamentales a la libertad y seguridad así como su derecho de defensa, arts. 17 y 24.2 CE. Denunciaba que a su abogado no le fue permitido tener acceso a la parte del atestado que se había ya redactado sobre los hechos investigados que justificaron su detención, lo que limitó indebidamente su derecho a conocer las razones de la detención, a contar con una asistencia letrada efectiva y a defenderse frente a una imputación penal. Dichas

\footnotetext{
33 Véase supra p. 9.
} 
vulneraciones no fueron reparadas por la resolución denegatoria del juez de guardia. Constata el TC que el demandante fue detenido por considerar que, junto con otros, había participado en la comisión de un delito de lesiones, y que, además de negar a su letrado el acceso a cualquier elemento del atestado, únicamente se le informó oralmente del hecho investigado - una agresión en grupo-, de su calificación jurídica — un delito de lesiones—y también de la fecha, hora y lugar en que se produjo la detención. El TC verifica la concurrencia de otras circunstancias que, siendo concluyentes en la decisión de detener al demandante y sus acompañantes, se omitieron al facilitarle la preceptiva información. Tales hechos omitidos debieron formar parte nuclear de la información facilitada al detenido y su letrado para objetivar, de ese modo, que se hallaba incurso en una de las causas de detención previstas por la ley. Por tanto, concluye el TC que la información suministrada fue insuficiente y debería haber sido completada o subsanada permitiendo el acceso del detenido o su letrado a las partes del atestado en las que constaban las circunstancias decisivas que justificaron la detención policial.

4. En la STC 4/2018 (Sala Segunda), de 22 de enero ${ }^{34}$, el objeto del recurso de amparo era determinar si el acuerdo de la Mesa del Parlamento de Canarias, por el que se inadmitieron las enmiendas al articulado presentadas por un grupo parlamentario a una proposición de ley, vulneró el derecho de los recurrentes a acceder y ejercer en condiciones de igualdad a las funciones y cargos públicos, art. $23 \mathrm{CE}$. Después de recordar la doctrina sobre el citado artículo y lo dicho por el TC en relación con el derecho a plantear enmiendas legislativas, señala que el Reglamento del Parlamento de Canarias dispone que corresponde a la Mesa de la Cámara, entre otras funciones, la de «calificar, con arreglo al Reglamento, los escritos y documentos de índole parlamentaria, así como declarar la admisibilidad o inadmisibilidad de los mismos mediante resolución motivada». Recuerda la sentencia que la Mesa inadmitió a trámite las enmiendas del grupo parlamentario recurrente en cuanto suponían en conjunto una enmienda a la totalidad encubierta, contradictoria con la toma en consideración del texto de la proposición de ley ya acordada por el Pleno de la Cámara. La Mesa afirmó que «no es posible que a través de lo que se presentan como enmiendas parciales, se pretenda anular por completo el contenido de la iniciativa legislativa, y vaciarla de contenido para volver a la regulación anterior, formulando, en realidad, una enmienda a la totalidad con texto alternativo que no difiere de la norma que se pretende reformar, extremo sobre el que ya se ha pronunciado el Pleno, al tomar en consideración la

34 Véase supra p. 242. 
proposición». Considera el TC que la decisión de la Mesa, si bien se adoptó formalmente al amparo del Reglamento del Parlamento de Canarias, al ser restrictivo del ius in officium de los parlamentarios, debería haber incorporado una motivación expresa, suficiente y adecuada para no vulnerar el art. 23.2 $\mathrm{CE}$, lo que no concurrió en el supuesto analizado. Concluye el TC que el acuerdo de la Mesa inadmitió a trámite las enmiendas presentadas por el grupo parlamentario recurrente sin cumplir con las exigencias de una motivación expresa, suficiente y adecuada.

En la STC 10/2018 (Sala Segunda), de 5 de febrero, la cuestión suscitada se centraba en determinar si los acuerdos de la Mesa del Parlamento de Cataluña, mediante los que se inadmitió la solicitud de los recurrentes para que el Consejo de Garantías Estatutarias emitiera un dictamen sobre la adecuación de la proposición de ley del referéndum de autodeterminación a la Constitución y al Estatuto de Autonomía de Cataluña, vulneraron el ejercicio de facultades que pertenecen al núcleo de la función representativa parlamentaria de los diputados demandantes, art. 23.2 CE. Recuerda el TC que los acuerdos de la Mesa impugnados formaron parte del procedimiento parlamentario seguido para la tramitación y final aprobación de la Ley del Parlamento de Cataluña 19/2017, de 6 de septiembre, del Referéndum de Autodeterminación, que fue declarada en su integridad inconstitucional y nula por la STC 114/2017, de 17 de octubre ${ }^{35}$. Tras recordar la doctrina constitucional sobre el art. 23.2 CE, se remite a lo establecido en la citada STC 114/2017 ${ }^{36}$, que hubo de dar respuesta a varias alegaciones de naturaleza formal, relativas al procedimiento parlamentario seguido para la aprobación de la ley y derivadas de una tramitación realizada en solo once horas y en cuyo curso se obviaron los derechos de los diputados a contar con la documentación objeto de debate y votación y la disposición de un plazo de 48 horas de antelación para su estudio y toma de posición; además, no fueron admitidas enmiendas a la totalidad de la proposición de ley y, únicamente, les fueron concedidas dos horas para

35 Reseñada en REDC 112, 2018, pp. 232-233; 247-247 y 262-263.

36 Además, recuerda que, con anterioridad a dicha sentencia, el Tribunal, mediante ATC 123/2017, de 19 de septiembre, estimó el incidente de ejecución de sentencia formulado por el abogado del Estado en representación del presidente del Gobierno y declaró la nulidad, tanto del acuerdo de la Mesa del Parlamento de Cataluńa, de 6 de septiembre de 2017, de admisión a trámite por el procedimiento de urgencia extraordinaria de la proposición de ley del referéndum de autodeterminación, como de los acuerdos del Pleno por los que se incluyó en el orden del día de la sesión de 6 de septiembre de 2017 el debate y votación de la referida proposición de ley, suprimiendo algunos trámites esenciales del procedimiento legislativo. 
la formulación y presentación de enmiendas al articulado; asimismo, se denegó al grupo parlamentario recurrente la tramitación de la solicitud de dictamen del Consejo de Garantías Estatutarias, que había formulado. Si bien es cierto, admite el TC, que la STC 114/2017 resuelve un recurso de inconstitucionalidad y, por tanto, en ella se realiza un análisis abstracto de los vicios de procedimiento como causa de la inconstitucionalidad de la norma y no, de forma específica, como eventuales vulneraciones de derechos o facultades atribuidos a los parlamentarios, no lo es menos que ambas cuestiones están directamente relacionadas. La inobservancia de los preceptos que regulan el procedimiento legislativo conduce a la inconstitucionalidad de la ley, precisamente, porque alteran «de modo sustancial, el proceso de formación de voluntad en el seno de las cámaras; tales reglas de procedimiento son invulnerables a la acción del legislador y tienen, sobre todo, un carácter instrumental respecto del pluralismo político, que es, con arreglo al artículo 1.1 CE, uno de los valores superiores del ordenamiento jurídico en general». En consecuencia, la argumentación recogida por la STC 114/2017 en relación con los vicios procedimentales en que incurrió el Parlamento de Cataluña al aprobar la ley del referéndum de autodeterminación tiene una conexión directa con el recurso de amparo analizado. En este sentido, reitera el TC que la proposición que dio lugar a la ley impugnada se tramitó y aprobó «al margen de cualquiera de los procedimientos legislativos previstos y regulados en el Reglamento del Parlamento de Cataluña y a través de una vía del todo inapropiada (artículo 81.3 RPC). De ella la mayoría se sirvió para improvisar y articular ad hoc un insólito cauce en cuyo curso quedaban por entero a su arbitrio las posibilidades de intervención y los derechos del resto de los grupos y diputados». La eliminación del trámite parlamentario consistente en la solicitud de dictamen al Consejo de Garantías Estatutarias sobre la conformidad de la proposición de ley del referéndum de autodeterminación a la Constitución y al Estatuto de Autonomía de Cataluña se realizó fuera de toda previsión del Reglamento del Parlamento de Cataluña y del resto del ordenamiento aplicable. Considera el TC que la supresión de la posibilidad de pedir dicho dictamen afectó a una facultad perteneciente al núcleo de la función representativa parlamentaria que se integraba en el ius in officium de los parlamentarios catalanes. En sentido similar se pronunció la STC 27/2018, de 5 de marzo.

En la STC 46/2018 (Pleno), de 26 de abril, la cuestión suscitada era determinar si la Mesa del Parlamento de Cataluña, al calificar y admitir a trámite la iniciativa presentada por determinados grupos parlamentarios por la que se solicitó la comparecencia ante el Pleno del Parlamento del presidente de la Generalitat de Cataluña con objeto de valorar los resultados del referéndum del día 1 de octubre y sus efectos de acuerdo con el art. 4 de la ley denominada 
«del referéndum de autodeterminación», vulneró el derecho al ius in officium, art. 23.2 CE, de los diputados recurrentes. Aducían los demandantes que los acuerdos impugnados al fundamentarse en una norma suspendida por una resolución del TC, cuya aplicación puede determinar la declaración formal de la independencia de Cataluña, supuso una "completa aniquilación» de su ius in officium «por la demolición ilegítima de todo el bloque de la constitucionalidad en Cataluña». Entiende la sentencia que el debido respeto a las resoluciones del TC y, en definitiva, a la Constitución que incumbe a todos los ciudadanos y cualificadamente a los cargos públicos les impide participar en un procedimiento parlamentario que tenga como objeto tramitar una iniciativa que de forma manifiesta desobedezca una decisión del TC. El incumplimiento de respetar lo resuelto por el TC por parte de la Mesa tiene una incidencia directa en el ius in officium de los miembros de la Cámara, pues si los parlamentarios participan en la tramitación de una iniciativa que contraviene de modo manifiesto un pronunciamiento del TC infringen también el deber de acatar la Constitución, art. 9.1 CE, y de cumplir lo que el TC resuelva. Por todo ello, concluye, la decisión de la Mesa Cámara constituye un manifiesto incumplimiento de su deber de respetar lo resuelto por el TC.

Por su parte, en la STC 47/2018 (Pleno), de 26 de abril, se recurrían los acuerdos de la Mesa del Parlamento de Cataluña, que, respectivamente, acordó el primero la calificación y admisión a trámite de las propuestas de resolución denominadas «Declaración de los representantes de Cataluña» y "Proceso constituyente», y desestimó el segundo la solicitud de reconsideración formulada. Frente a la actuación de la Mesa del Parlamento catalán, favorable a dar curso a aquellas propuestas de resolución para su debate y votación en el Pleno, se denunciaba por los recurrentes la vulneración de las facultades del ius in officium que les son inherentes, en cuanto parlamentarios que ostentan la representación de los ciudadanos de Cataluña. Considera el TC que la decisión de la Mesa del Parlamento de calificar y admitir a trámite las propuestas de resolución, desatendiendo las advertencias de los servicios jurídicos del Parlamento y los requerimientos de las resoluciones del TC, provocó una primera consecuencia que afectó hondamente a la situación parlamentaria de los recurrentes, que se vieron en la tesitura obligatoria de tener que optar entre atender al mandato representativo de los ciudadanos por los que habían resultado elegidos, para lo cual tendrían que asistir a un Pleno en el que se iban a debatir, contra la prohibición expresa de este TC, determinadas propuestas de resolución manifiestamente inconstitucionales; o no asistir a la sesión plenaria, lo que les llevaría a tener que ausentarse del Pleno, para desvincularse de aquellas iniciativas prohibidas, desatendiendo de ese modo sus funciones como tales parlamentarios electos. Tal obligación de tener que optar entre 
ambas posibilidades implicaba una grave afectación del ius in officium de los diputados recurrentes, pues estos habrían de debatirse entre tomar parte en una sesión parlamentaria con un contenido claramente contraventor de la Constitución y de la legalidad, dando una apariencia de normalidad parlamentaria y democrática a un acto que no la tenía, o ausentarse del mismo y no participar en el debate y votación, teniendo que renunciar obligatoriamente a sus funciones más características, como parlamentarios representantes de los ciudadanos que los eligieron.

5. En la STC 22/2018 (Sala Primera), de 5 de marzo ${ }^{37}$, el recurrente, funcionario autonómico interino, vio su jornada reducida con la consiguiente reducción retributiva. La queja principal se dirige contra la sentencia impugnada, a la que él reprochaba no haber respondido a su solicitud de aplicación directa de la directiva 1999/70/CE y, en consecuencia, por no haber aplicado esta para estimar su pretensión, lo que supone una lesión del derecho a la tutela judicial efectiva. En cuanto a la falta de respuesta a la cuestión de la procedencia de aplicar directamente la directiva 1999/70/CE, recuerda el TC que el juzgado dejó de razonar sobre un alegato sustancial de la parte actora, como era la existencia de esos precedentes provenientes del Tribunal de Justicia de la Unión Europea encargado de resolver de manera vinculante las dudas sobre la interpretación de la directiva invocada. Reitera el TC que aunque no hay un derecho de la parte en un proceso al planteamiento de la cuestión prejudicial, el órgano judicial, ante la puesta de manifiesto de la necesidad u oportunidad de la misma, debe motivar suficientemente su opción. En consecuencia, estima el TC que el recurrente no obtuvo, en relación con la procedencia de que le fuera o no aplicado directamente el ordenamiento comunitario, la respuesta que era exigible para obtener la tutela judicial efectiva a la que, en forma de resolución judicial fundada, tenía derecho.

En la STC 24/2018 (Sala Primera), de 5 de marzo $^{38}$, el problema consistía en determinar si el auto del Juzgado Central de Instrucción, así como el auto de la Audiencia Nacional que lo confirmó en apelación, vulneraron los derechos del recurrente a la tutela judicial efectiva sin indefensión y a la defensa, a conocer la acusación y a un proceso con todas las garantías. Esas resoluciones judiciales denegaron al recurrente, por no encontrarse a disposición del juez instructor, su pretensión de personarse en las diligencias previas por medio de procurador, a fin de recurrir la orden de búsqueda y detención dictada en su contra. Explica el TC que el deber jurídico de comparecencia

37 Véase supra pp. 245-246.

38 Véase supra p. 239. 
personal para ejercer la defensa en el proceso penal ordinario y en el procedimiento abreviado responde a una finalidad constitucional legítima, toda vez que la presencia del investigado o acusado puede ser conveniente y aún necesaria para el esclarecimiento de los hechos, sin perjuicio del interés general en que aquel se encuentre a disposición de la justicia para sufrir, en su caso, el cumplimiento coactivo de la pena. Así, los derechos a la defensa y a ser defendido por abogado pueden ceder ante los límites que la propia Constitución expresamente imponga o ante los que de manera mediata o indirecta se infieran de la misma al resultar justificados por la necesidad de preservar otros derechos o bienes jurídicamente protegidos. El investigado o acusado debe estar en persona a disposición de los tribunales; ahora bien, cualquier sanción procesal que pretenda anudarse a la incomparecencia injustificada de aquel ha de ser proporcionada a la conducta que se sanciona y, por consiguiente, no puede alterar las garantías básicas del proceso justo. Por ello, para que pueda entenderse compatible con el derecho de defensa una decisión judicial de rechazo de la personación del investigado, con fundamento en que aquel se encuentra sustraído a la acción de la justicia, resulta necesario que la negativa judicial supere las exigencias del juicio de proporcionalidad. Considera el TC que la argumentación del juzgado de que la ausencia del investigado se debe a su propia decisión, vinculada a la idea del abuso de derecho y la estrategia procesal fraudulenta, elude toda consideración de las razones alegadas por el recurrente sobre la inexistencia de citación para comparecer durante la dilatada instrucción, así como sobre su voluntad de colaboración efectiva con la justicia española. Censura el TC que el juzgado prescindiera de toda ponderación de las circunstancias alegadas por el recurrente en amparo para solicitar su personación en el proceso mediante procurador, por lo que el rechazo judicial de esta pretensión no satisface las exigencias constitucionales del principio de proporcionalidad.

6. En la STC 12/2018 (Pleno), de 8 de febrero ${ }^{39}$, el objeto era la resolución administrativa por la que se impuso al demandante de amparo la sanción de suspensión firme de funciones y retribuciones de treinta días como responsable de una falta leve por «el incumplimiento de los deberes y obligaciones del personal funcionario, siempre que no deba ser calificado como falta muy grave o grave». La conducta por la que se impuso la referida sanción consistió en que el día previo a la celebración de una huelga y sin conocimiento del centro, el recurrente, funcionario de carrera del cuerpo de maestros y tutor de educación primaria, entregó a sus alumnos una nota personal dirigida a la

39 Véase supra p. 241. 
atención de sus padres, en la que informaba de la convocatoria de dicha huelga y mediante la que, tras relacionar las razones que consideraba existentes para secundarla, comunicaba que la secundaría y que sus hijos no serían atendidos por él, en cuanto tutor de los referidos alumnos ${ }^{40}$. Según se desprende de la argumentación empleada en el expediente disciplinario, los deberes y obligaciones del personal funcionario que la Administración sancionadora considera incumplidos por el recurrente se concretan en dos conductas diferentes: la primera consiste en utilizar recursos y bienes públicos para usos particulares. Se consideró que «el empleo realizado por el profesor de bienes públicos, como son la jornada de trabajo y los canales de información a los padres y madres, para difundir sus opiniones personales sobre las decisiones adoptadas por sus superiores en materia educativa, está subsumido en el efectivo incumplimiento de sus deberes y obligaciones como funcionario». Pues bien, considera el TC que, de las actuaciones obrantes en el expediente se deduce que el comportamiento del profesor no tiene encaje en el tipo sancionador que apreció la Administración, dada la índole de la información transmitida y el escaso tiempo de clase dedicado a facilitarla. La segunda conducta en la que se concreta el incumplimiento de los deberes y obligaciones como personal funcionario del recurrente en amparo es la infracción del deber de neutralidad. Entiende el TC que por lo que se refiere, en primer lugar, a la comunicación dirigida a los padres, no puede entenderse vulnerado el deber de neutralidad exigible a los empleados públicos al no haber acreditado en el expediente que el recurrente haya comprometido con su actuación el buen funcionamiento del servicio público docente. Dado el nivel de certeza que exige el ejercicio de la potestad sancionadora, no se puede concluir que la carta remitida a los padres posea un contenido informativo que se pueda entender vulnerador del deber de neutralidad funcionarial, teniendo en cuenta además que no eran los

40 El recurrente afirmó en primera persona: «Considero que existen una serie de razones para secundarla y que quiero exponerles», pasando seguidamente a señalar tales motivos, a los que añadía el anuncio realizado por la entonces Sra. Presidenta de Castilla-La Mancha «de que se favorecerán los conciertos educativos (según nuestro Consejero de Educación, el elevado fracaso escolar en nuestra región es debido a que hay más enseńanza pública que privada)», e indicando al final que "atendiendo a las razones expuestas y al derecho constitucional que me asiste, les comunico que secundaré la huelga y sus hijos no serán atendidos por su tutor». El recurrente solicitó además a los alumnos que anotaran en sus agendas escolares el recordatorio de entregar a sus padres la circular del tutor sobre la huelga. En tales acciones empleó en torno a diez minutos del horario lectivo, durante los que también indicó a sus alumnos su intención de ejercer su derecho de huelga. 
alumnos los destinatarios de la nota. Y, por lo que se refiere, en segundo lugar, a la explicación a los alumnos durante la clase de las razones de la huelga, queda acreditado en el expediente que al ser preguntados los alumnos acerca de aquella explicación respondieron que el profesor «dijo que él quería ir a la huelga para ver si se solucionaban los motivos que explicaba» en la nota; y que «iba a hacer huelga porque iba a haber recortes en el presupuesto». A la vista de lo expuesto, lo único que cabe considerar acreditado es que el demandante informó a los alumnos sobre la convocatoria de huelga y su voluntad de secundarla. Por tanto, no queda acreditado el incumplimiento de los deberes que, según la resolución sancionadora, determinan la comisión de la conducta infractora. Consiguientemente, al haber sido sancionado el recurrente en amparo por una conducta que, según los hechos acreditados, no constituye un incumplimiento de sus deberes como funcionario, debe estimarse la vulneración del art. 25.1 CE, evitándose así el «efecto desaliento» en el ejercicio de los derechos fundamentales ${ }^{41}$.

41 Carlos Ortega Carballo. 